\title{
Apelin Over-Expression Promotes Proliferation and Angiogenesis of Gastric Cancer Cells
}

\section{LiJun Tian}

Binzhou Medical College: Binzhou Medical University

Hong-Zhi Liu

Binzhou Medical College: Binzhou Medical University

Qiang Zhang

Binzhou Medical College: Binzhou Medical University

Dian-Zhong Geng

Binzhou Medical College: Binzhou Medical University

Jing Yang

Binzhou Medical College: Binzhou Medical University

Hai-Tao Geng

Binzhou Medical College: Binzhou Medical University

\section{Yu-Jie Zhai}

Binzhou Medical College: Binzhou Medical University

\section{Yu-Qing Huo}

Binzhou Medical College: Binzhou Medical University

YanZhang Hao ( $\square$ byfyhyz@bzmc.edu.cn )

Binzhou Medical College affiliated Hospital https://orcid.org/0000-0002-2325-9280

\section{Research}

Keywords: Apelin, gastric cancer, tumor growth, signal pathway

Posted Date: June 8th, 2021

DOl: https://doi.org/10.21203/rs.3.rs-530677/v1

License: (c) (i) This work is licensed under a Creative Commons Attribution 4.0 International License.

Read Full License 


\section{Abstract}

Background: Apelin is a recently identified endogenous ligand associated with proliferation and angiogenesis of several cancers. However, only few studies have reported on the functions and the role of apelin in gastric cancer (GC). Therefore, in the present study, we investigated the association and the mechanisms underlying Apelin expression and proliferation of GC cells both in vitro and in vivo.

Methods: We enrolled 178 postoperative care GC patients to investigate clinicopathological and immunohistochemical factors associated with Apelin expression. The relationship between Survival of patients and apelin expression was evaluated using Kaplan-Meier method and Cox regression analyses. The expression of apelin mRNA and its proteins in GC tissues and cell lines were analyzed using quantitative real-time reverse transcription-polymerase chain reaction (RT-PCR), western blot and ELISA. The role and mechanisms underlying regulation of Apelin expression in human GC cells were evaluated through several in vitro and in vivo experiments.

Results: Apelin was over expressed in human GC cells, relative to adjacent normal tissues. The over expression of apelin was associated with vessel invasion $(P<0.01)$, lymph node metastasis $(P<0.01)$, late-staged tumor $(\mathrm{T})(P<0.05)$, worse pathological type $(P<0.05)$, nerve invasion $(P<0.05)$. In addition, expression of apelin strongly and positively correlated with that of vascular endothelial growth factor (VEGF). Over-expression of apelin promoted proliferation and invasion of MGC-803 cell via the ERK/Cyclin D1/MMP-9 signaling pathway. Apelin over-expression also promoted angiogenesis of GC cells, accelerating growth of subcutaneous xenograft of the cancer cells in vivo.

Conclusions: Over-expression of apelin promotes proliferation and metastasis of GC cells via the ERK/Cyclin D1/MMP-9 signaling pathway and is associated with adverse events of the cancer. Consequently, apelin is a potential therapeutic target for human GC.

\section{Background}

Gastric cancer (GC) is the fifth most prevalent and aggressive malignancy and the third most fatal cancer globally $[1,2]$. Despite the recent advances such as radical surgical resection, adjuvant chemoradiation and targeted therapy, the prognosis for GC patients remains poor, with the overall 5-year survival rate only between $20-40 \%$ [3-5]. Although several studies have identified numerous proteins associated with the clinical outcomes of GC patients, none of them has proposed early and accurate diagnostic as well as prognostic molecular marker for GC [6, 7].

Apelin is a bioactive peptide recently identified as an endogenous ligand that binds APJ, a human G protein-coupled receptor [8]. Apelin, a member of the adipokine family secreted by adipose tissue, is expressed in numerous cell types [9]. The Apelin gene encodes a prepropeptide consisting of 77 amino acids that promotes proteolytic maturation and subsequently generate different bioactive peptide fragments: Apelin-17, Apelin-36 and Apelin-13, all predominant in human plasma [8, 9]. Apelin/APJ signaling pathway, mostly associated with the cardiovascular system, participates in numerous 
physiological and pathological processes such as angiogenesis, heart failure, energy metabolism and cancer progression $[9,10]$. Dysfunctional and abnormal vasculature plays a critical role in the development and growth of tumors [10-12]. Accordingly, abnormal expression of VEGF and its receptor, associated in angiogenesis, have been therapeutic cancer targets for over 30 years [11, 12]. Apelin overexpression stimulates proliferation of endothelial cells, enhances tumor vascularization and accelerating formulating capillary tubes demonstrated both in vivo and in vitro[13, 14]. In addition, over expression of Apelin is associated with poor clinical outcomes in patients with certain cancers $[15,16]$.

However, the role and molecular mechanisms of Apelin in GC is not well understood. Therefore, we investigated the correlation between Apelin expression and clinical outcomes of human GC and as well the mechanisms underlying Apelin expression and the occurrence of adverse events in GC cells.

\section{Patients And Methods}

\section{Patients}

We analyzed histopathologically confirmed GC cancer tissues of 178 patients attending the Binzhou Medical College Affiliated Hospital between January 2009 and December 2011. The patients underwent radical D2 lymphadenectomy followed by chemotherapy alone or in combination with radiotherapy. All patients underwent computed tomography (CT) of the neck, chest and abdomen. The anti-tumor therapies were only administered after surgery. Postoperative chemotherapy with fluoropyrimidine or capecitabine in combination with oxaliplatin or paclitaxel, repeated for at least 4 cycles, was introduced one month after the surgery. Eligible patients underwent intensive modulation radiotherapy (IMRT) of 4550.4 Gy, given in 1.8-2.0 Gy fractions. The progression-free survival (PFS) time was defined as the period between the operation and the re-ccurrence of the cancer, death of the patient or the end of the study. Overall survival (OS) was assessed between time of surgery to death or December 31, 2016.

\section{Immunohistochemical analysis}

Immunohistochemical analyses were performed on tumor tissues previously fixed in formalin and embedded in paraffin. The tissue sections $(4 \mu \mathrm{m})$ were deparaffinized with xylene and rehydrated in several dilutions of alcohol. Heat-induced antigen retrieval was performed in $0.01 \mathrm{M}$ citrate buffer $(\mathrm{PH}=6)$ for 5 minutes, before heating the slides for 15 minutes at $x y z^{\circ}$. The tissue sections were incubated in $3 \%$ $\mathrm{H}_{2} \mathrm{O}_{2}$-methanol solution at $37.0^{\circ} \mathrm{C}$ for 20 minutes to block endogenous peroxidase. Thereafter, the tissues were blocked for 10 minutes in albumen, before overnight incubation at $4^{\circ} \mathrm{C}$ with anti-Apelin, anti-VEGF or anti-CD34 antibodies at dilution ratios of 1:200, 1:100 or 1:200, respectively (Abcam, the USA). The tissues were stained and counter stained with diaminobenzidine and Mayer's modified hematoxylin respectively, and viewed using the EnVision-HRP detection system (Dako, Carpinteria, CA, the USA). Tissues were then incubated at $37^{\circ} \mathrm{C}$ for 30 minutes with $80 \mu \mathrm{L}$ horseradish peroxidase conjugated goat anti-rabbit or rabbit anti-mouse immunoglobulins $\mathrm{G}(\mathrm{IgG})$ (1:250) (Dako, Carpinteria, CA, the USA). The tissues were evaluated independently by two investigators, oblivious to the clinical data of the patients. Disagreements were resolved through discussion. Apelin or VEGF immunostaining score was calculated 
by multiplying the positive cell area score and the staining intensity score. An immunoexpression score > 3 was considered positive, with those $\leq 3$ was considered negative. The staining intensity was classified into four levels: no staining (0), light staining (1), moderate staining (2) and deep staining (3). The positive cell area score was based on the percentage of positive cells, classified as follows: Negative (0), less than $10 \%$ positivity (1), $11-50 \%$ positivity (2), $51-75 \%$ positivity (3) and greater than $76 \%$ positivity (4) $[15,16]$. Microvessel densities (MVD) were established after labeling the capillaries $(0.02-0.10 \mathrm{~mm})$ with CD34 (Dako, Carpinteria, CA, the USA). Morphometric analysis of three sections per slide was performed using computer-aided CUE-2 software (Olympus Vanox, Tokyo, Japan) as previously described [17].

\section{Cell culture}

HGC-27, MGC-803 and SGC-7901 human GC cell lines were purchased from Anhui Medical University (Anhui, China). They were all cultured in Dulbecco's Modified Eagle Medium (DMEM, Gibco, CA, the USA) supplemented with $10 \% \mathrm{FBS}$ (Gibco, CA, the USA) at $37^{\circ} \mathrm{C}$ under $5 \% \mathrm{CO}_{2}$.

\section{Construction of stable transfected cell lines}

Apelin complementary DNA was purchased from Thermo Fisher Scientific (Shanghai, China). DNA encoding areas were amplified using the following primers: 5'-CGCGAATTCGGCATGAATCTGCGGCTCTG3'and 5'-GCGCTCGAGTCAGAAAGGCATGGGTCC-3'. The amplified PCR products were ligated to Apelin cDNA and cloned into the pcDNA vector containing EcoRI and Xhol restriction sites (Invitrogen, Carlsbad, CA, USA). The expression of the hybrid DNA in the vectors was validated by sequencing. The MGC- 803 cell were transfected with the pcDNA 3.1 or empty vectors using the Lipofectamine 2000 transfection reagent (Thermo Fisher Scientific, Shanghai, China), according to the manufacturer's protocol.

\section{RNA isolation and quantitative real-time reverse transcription-polymerase chain reaction}

Total RNA from each human GC cell line was extracted using TRIzol (Invitrogen, Carlsbad, CA, the USA), following the manufacturer's protocol. Corresponding CDNA was synthesized through reverse transcription of the RNA, using the murine leukemia virus. The resultant DNA was amplified under the following cyclic conditions through 42 cycles: initial denaturation $95^{\circ} \mathrm{C}$ for 20 seconds, subsequent denaturations at $95^{\circ} \mathrm{C}$ for 5 seconds, annealing elongation at $60^{\circ} \mathrm{C}$ for 30 seconds. PCR products were stained with ethidium bromide, separated through gel (2\%) electrophoresis and visualized under UV. The primer sequences for PCR were as follows: Apelin: 5'-GATGCCGCTTCCCGATG-3'(forward) and 5'ATTCCTTGACCCTCTGGGCT-3'(reverse), $\beta$-actin; 5'-TGCTGTCCCTGTATGCCTCT-3' (forward) and 5'AGGTCTTTACGGATGTCAACG-3' (reverse). The expression levels of mRNA for the above proteins were calculated based on the $2^{-\triangle \Delta C t}$ method [18]. Gene expression level of Apelin mRNA in MGC-803 cell line was determined using the same method, 48 hours after transfection with control or Apelin-encoding pc DNA 3.1 vector.

\section{Protein Extraction and Western Blot analysis}


Cultured cells at logarithmic growth phase were resuspended in lysis buffer containing $5 \mu \mathrm{L}$ Protease Inhibitor Cocktail (cOmplete, Sigma, Germany) before lysis as previously [19]. The concentration of xyz proteins in the supernatants was measured using the Bradford protein assay kit (Bio-Rad, Hercules, CA, the USA). Equal amounts of protein samples ( $80 \mu \mathrm{g} / \mathrm{lane}$ ) were fractionated on $10 \%$ sodium dodecyl sulfate (SDS)-polyacrylamide gel and transferred onto polyvinylidene fluoride (PVDF) membranes at $0.8 \mathrm{~mA} / \mathrm{cm}^{2}$ for $20-30$ minutes. The membranes were blocked for 2 hours at $37^{\circ} \mathrm{C}$ with Tris-buffered saline (TBS) containing $10 \%$ nonfat milk before overnight incubation at $4{ }^{\circ} \mathrm{C}$ with primary antibodies against Apelin, $\beta$-actin, pERK, pAkt, Cyclin D1 and MMP-9. Membranes were washed four times with TBST and thereafter incubated for 2 hours at $37.0^{\circ} \mathrm{C}$ with horseradish peroxidase (HRP)-conjugated secondary antibodies. The proteins were visualized after staining with the ECL reagent and thereafter quantified using the Quantity One software. The dilutions for the primary antibodies were as follows; 1:200 for antiApelin (Phoenix Pharmaceuticals, USA), 1:2,000 for anti- $\beta$-actin (Maxim, China), 1:200 for ant-pERK (Cell Signaling Technology, France), 1:1000 for anti-pAkt (Santa Cruz, USA), 1:200 for anti-Cyclin D1 (Santa Cruz, USA) and 1:200 for anti-MMP-9 (Santa Cruz, USA). Proteins were extracted from MGC-803 cells for western blotting after 48 hours of transfection with pcDNA3.1-Apelin or control vectors following activation with Apelin-13 (Phoenix Pharmaceuticals, Inc, the USA). Analysis of pERK, pAkt, Cyclin D1 and MMP-9 expression in MGC-803 cells was performed as described in the preceding sections.

\section{ELISA}

The concentrations of Apelin in MGC-803 cell culture supernatants $(500 \mu \mathrm{L})$ were measured using human Apelin ELISA kit (Phoenix Pharmaceuticals, USA) following the manufacturer's instructions. Similarly, the concentration of Apelin after transfection with pcDNA3.1-Apelin or control vector was performed in similar manner. The experiments were performed in duplicate

\section{Cell Proliferation assays}

To assess cell proliferation, cells $\left(1 \times 10^{4} /\right.$ well) well were seeded in flat-bottomed 96-well microplates and cultured for 24 hours. Then the cells were washed twice using PBS and cultured in DMEM supplemented $0.5 \%$ FBS for 12 hours. The cells were treated with MTT $(5 \mathrm{mg} / \mathrm{mL})$ for 4 hours at $37.0^{\circ} \mathrm{C}$ after $24 \mathrm{~h}$ incubation with different concentrations of Apelin-13 $(0.02 \mu \mathrm{mol} / \mathrm{L}, 0.1 \mu \mathrm{mol} / \mathrm{L}, 0.5 \mu \mathrm{mol} / \mathrm{L}$, $2.5 \mu \mathrm{mol} / \mathrm{L} 12.5 \mu \mathrm{mol} / \mathrm{L}, 62.5 \mu \mathrm{mol} / \mathrm{L})$, the cells were treated with. Thereafter, $150 \mu \mathrm{L}$ of dimethyl sulfoxide (DMSO) was added to each well to remove cells that were not reduced by MTT reagent. The absorbance of cell supernatants was measured at $570 \mathrm{~nm}$ using a microplate reader (MA, USA). The absorbance was also measure at $570 \mathrm{~nm}$ using the optimal concentration obtained from the previous experiment at different time points $(6 \mathrm{~h}, 12 \mathrm{~h}, 24 \mathrm{~h}, 36 \mathrm{~h}$ and $48 \mathrm{~h})$. The absorbance was also measured at $570 \mathrm{~nm}$ at the aforementioned time points to validate change in cell proliferation after transfection with pcDNA 3.1 or pcDNA 3.1-Apelin vector.

\section{Cell Migration and Invasion Analysis}


The migration and invasion of cells were evaluated using the Transwell chambers (BD, the USA). Briefly, MGC-803 cells were divided into 4 groups: Non-treatment group, Apelin-13 treatment group, pcDNA 3.1transfection group and pcDNA 3.1-Apelin - trasnfection group. The cells $\left(5 \times 10^{4}\right.$ cells/ well $)$ were seeded in the upper chamber pre-coated with serum free Matrigel (BD, the USA). The lower chamber contained $600 \mu \mathrm{L}$ of DMEM. After $24 \mathrm{~h}$ of incubation, cells that had not penetrated the membrane were removed. Cells that migrated across the membrane were counted using an inverted microscope at $200 \times$ magnification (Olympus, Japan), after 15 minutes staining with $4 \%$ polyoxymethylene and $0.2 \%$ crystal violet.

\section{Apoptosis of MGC-803 cell}

Apoptosis of MG-803 cells was induced using Suberoylanilide hydroxamic acid (SAHA) [20], a member of histone deacetylase inhibitor (HDACl) family. Here, MGC-803 cells were divided into 5 subgroups: Controls, SAHA- treatment group $(2 \mu \mathrm{mol} / \mathrm{L}$ for 24 hours), SAHA + Apelin-13 treatment group $(2.5 \mu \mathrm{mol} / \mathrm{L}$ for 24hours), SAHA + pcDNA3.1 treatment group (24hours after transfection) and SAHA + pcDNA3.1Apelin treatment group (24hours after transfection). After re-suspension in $300 \mu \mathrm{L}$ of binding buffer (BD, USA), the cells were mixed with $5 \mu \mathrm{L}$ of Annexin V-FITC for 15 minutes and thereafter in $5 \mu \mathrm{L}$ of propidium iodide (PI) for 5 minutes at $37.0^{\circ} \mathrm{C}$, both in the dark. Finally, cells were mixed with $200 \mu \mathrm{L}$ of binding buffer and examined using a flow cytometer (BD, USA). U1 subset (Annexin V-FITC (-)/ PI (+)) represented the degree of necrosis, U2 subset (Annexin V-FITC $(+) / P I(+))$ represented late-staged apoptosis, U3 subset (meaning Annexin V-FITC (-)/PI (-)) represented the control whereas U4 subset (Annexin V-FITC (+)/PI (-)) represented early-staged apoptosis. The rate of apoptosis was calculated as: (U2 + U4) / (U1 + U2 + U3 + U4) $\times 100$.

\section{Construction of MGC-803 cell stably expressing Apelin}

To determine the optimal concentration of puromycin (Beijing, China), cells $\left(2 \times 10^{4}\right.$ cells $/$ well) at the logarithmic phase were cultured overnight in 24-well microplates under different puromycin concentrations $(0,1,2.5,5,7.5,10,15 \mu \mathrm{g} / \mathrm{mL})$. We found $7.5 \mu \mathrm{g} / \mathrm{mL}$ of puromycin (the lowest concentration) killed all MGC-803 cells after 72 hours of treatment, thus was selected for subsequent experiments. MGC-803 cells were cultured in 24-well plates containing FBS or antibiotic free DMEM. The cells were cultured to $80 \%$ confluent. The cells were further incubated at $37^{\circ} \mathrm{C}$ for 4 hours after addition of a mixture of $2 \mathrm{~mL}$ polybrene (Beijing. China) (final concentration $6 \mu \mathrm{g} / \mathrm{mL}$ ) and viral supernatant $(0.5 \mathrm{~mL}$ ). Thereafter, fresh DMEM was added in each well followed by another $24 \mathrm{~h}$ incubation at $37^{\circ} \mathrm{C}$. Puromycin $(7.5 \mu \mathrm{g} / \mathrm{mL})$ was added to each well after 3 days, followed by $\mathrm{x} h$ incubation at $37^{\circ} \mathrm{C}$. The medium was changed every 2-3 days until colonies were formed. Negative colonies were removed, whereas the puromycin-resistant colonies were transferred to a 24-well microplate divide to more than half of the dish. mRNA and protein expression of target genes were determined using RT-PCR and Western blot assays, respectively.

\section{Subcutaneous xenografts in vivo}


Fourteen nude BALB/c nu/nu, female, 5- 6 weeks old mice were purchased from the Laboratory Animal Resources of Chinese Academy of Sciences (Shanghai, China). The mice were raised in pathogen-free conditions. The xenograft tumors were established by subcutaneous injection of $0.2 \mathrm{~mL}$ MGC-803 cells $\left(1 \times 10^{7} / \mathrm{mL}\right)$ stably expressing Apelin or control into the mice. The long diameter (a), short diameter (b) and weight of the tumors were measured twice a week by the same investigator. The tumor volumes $\left(\mathrm{mm}^{3}\right)$ was calculated based on $\mathrm{V}=\mathrm{ab}^{2} / 2$. The resultant volumes were used to plot a tumor growth curve. Mice were euthanized after 35 days of xenograft for further analyses. The tumor proliferation rate was calculated as; (the averaged weight of xenograft tumors in the experiment -the averaged weight of control group)/ the averaged weight of xenograft tumors $\times 100 \%$.

\section{Immunohistochemistry of MVD in Vivo}

Immunohistochemical staining was performed for MVD in murine tumors as described in the previous section.

\section{Statistical Analysis}

Data was analyzed using SPSS software, version 16.0 (NY, USA). The association between clinicopathologic factors and Apelin as well as VEGF expression was analyzed using chi-square test. Continuous variables such as MVD were expressed as mean \pm S.E.M. Differences between groups were analyzed using Student $t$-test or nonparametric tests. The association between expression of Apelin and VEGF was analyzed using Spearman's rank correlation test. The association between Apelin and prognosis of GC was assessed using Kaplan-Meier, Cox proportional hazards survival analyses and logrank test. $P<0.05$ was considered statistically significant.

\section{Results}

Among the 178 participants, 141 (79.21\%)were males whereas 37 (20.79\%)were females, with a combined median age of 62 years (range 34-38 years). In addition, 61, 14, 49 and 54 patients presented with primary lesions in the cardiac region, gastric fundus, gastric body and gastric antrum, respectively. The tumors were divided into well or moderately differentiated ( 82 cases), poorly differentiated (75 cases), mucinous adenocarcinoma (17 cases) and signet ring cell carcinomas ( 2 cases) based on the degree of differentiation, based on the AJCC/UICC TNM classification method, revised in 2010. In addition, 5, 98, 75 patients presented with I, II and staged III, respectively, of GC. Immunohistochemical analyses revealed Apelin was expressed in 53 of 178 normal gastric tissues adjacent to tumor tissues and 88 of 178 tumor tissues $(29.78 \%$ vs $49.44 \%, P<0.001$, Table 1.1 ). Additionally, immunostaining revealed that in tumor tissues, apelin was mostly distributed in the cytoplasm (Figure 1.1). On the other, VEGF was expressed in $55.62 \%$ of tumor cells, compared to $39.89 \%$ in adjacent normal tissues $(P=0.003$, Table 1.1). Similarly, just like apelin, VEGF proteins displayed cytoplasmic distribution (Figure 1.2). Chisquare test revealed that apelin expression was strongly and positively correlated with vessel invasion and lymph node metastasis ( $P<0.01)$, $(P<0.01)$ (Table 1.2). In addition, Apelin expression was associated with late-staged tumor $(T)$, pathological type and nerve invasion $(P<0.05)$. Contrarily, we 
found no significant associations between Apelin expression and gender, age and the site of primary lesion ( $P>0.05)$. Meanwhile, VEGF expression was significantly high during late $T$ stage $(P<0.01)$, vessel invasion and $\mathrm{N}$ stage $(\mathrm{P}<0.05)$. However, there was no significance difference in VEGF expression between gender, across age groups, site of primary lesion, pathological type and nerve invasion $(P>0.05)$. Meanwhile, the MVD was greater in Apelin positive $(33.086 \pm 7.862 ; P<0.05)$ than Apelin-negative $(21.071 \pm 6.320)$ tumor tissues. Similarly, a statistically significant difference was observed between the VEGF-positive subgroup with high MVD expression (29.075 \pm 8.193 ) and VEGF-negative subgroup with low MVD expression (19.638 $\pm 5.614 ; \mathrm{P}<0.05)$ (Table 1.3 and Figure 1.3). Immunohistochemical analyses further revealed that VEGF was expressed in more 72.7\% (64/88) Apelin-positive tumor cells than Apelinnegative tumor cells 38.9\% (35/90). In the reverse, Apelin was expressed in 64 (64.6\%) of 99 VEGFpositive tissues, compared to 24 (30.3\%) of 79 of VEGF-negative tissues. Overall, expression of Apelin proteins strongly and positively correlated with that of VEGF $(R=0.856 ; P<0.01$, Table 1.4). The 1 year, 3 years and 5 years OS rates of patients expressing Apelin were $97.73 \%, 62.50 \%$ and $28.41 \%$, respectively (Figure 1.4). That of patients not expressing Apelin were $97.78 \%, 76.67 \%$ and $53.33 \%$ for respective 1 year, 3 year and 5 year OS. The median OS of patients with Apelin positive tissues was 40.7 months, compared to 60.2 months for Apelin negative patients $(\chi 2=12.549, P<0.001)$. The 1 year PFS rates of patients not expressing Apelin was $94.44 \%$, compared with $96.60 \%$ of those not expression apelin. For 3 year PFS, that of apelin positive patients was $65.56 \%$, compared to $44.32 \%$ of apelin negative patients. On the other hand, the 5 year PFS of patients not expression apelin was $40.00 \%$, compared to $19.32 \%$ for apelin negative patients (Figure 1.5). Furthermore, there was a substantial difference in median PFS between apelin negative and apelin positive groups ( 49.8 months vs 30.5 months, $\chi 2=9.537, P=0.002$ ). Overall, Apelin expression was associated with poor OS and shorter PFS. Univariate Cox proportional hazards analysis revealed that except for gender, age and the site of primary tumor or nerve invasion, Apelin and VEGF expression, $T$ stage, lymph node $(\mathrm{N})$ stage, vessel invasion and histological type (all $\mathrm{P}$ $<0.05$ ) were all associated with poor prognosis of GC (Table 1.5). Further multivariate regression analysis revealed that lymph node metastasis $(P<0.001)$, late-staged status $(P=0.008)$, poor differentiation $(P=0.027)$ and histological type (including mucinous adenocarcinoma, signet ring cell carcinoma and small cell carcinoma) were independent factors associated with poor prognostic and OS of GC ( $P=0.012)$ (Table 1.6). Cell culture tests further validated the over-expression of apelin in MGC-803, SGC-7901 and HGC-27 GC cell lines. RT-PCR further revealed that the expression of apelin mRNA was significantly higher in MGC-803, SGC-7901 and HGC-27 GC cell lines than normal adjacent cells ( $P<0.05$, Figure 2.1). Apelin was expressed lowest in MGC-803 cells ( $\mathrm{Ct}=1.000 \pm 0.344)$, a 30-fold difference when compared with HGC27 cells $(\mathrm{Ct}=29.755 \pm 5.067)$. Western blot revealed that Apelin proteins were expressed lowest in MGC803 cells, consistent with qRT-PCR analyses $(P<0.05)$. ELISA test also revealed that Apelin protein and its mRNA were expressed lowest in MGC-803 cells $(132.00 \pm 31.97 \mathrm{pg} / \mathrm{mL})(P<0.05$, Figure 2.3). The pcDNA3.1-Apelin vector transfected MGC-803 cells were selected for subsequent analyses, down to the lowest Apelin expression. We found Analyses Apelin mRNA and Apelin proteins were over-expressed in MGC-803 cells, relative to controls. Moreover, Apelin expression improved significantly, after transfection with pcDNA3.1-Apelin (Figure 2.4, 2.5 and 2.6). MTT assay revealed that inhibition of Apelin expression modulated the proliferation of GC cells in a concentration and time dependent manner, with $2.5 \mu \mathrm{mol} / \mathrm{L}$ of 
Apelin-13 being the optimal concentration (Figure 2.7 and Figure 2.8). The proliferation rate of pcDNA3.1Apelin vector trasnsfected MGC-803 cells was greater than that of control within 24-48 hours of incubation (Figure 2.9) The migration and invasion assay of MGC-803 cells revealed that compared to controls, Apelin-13 positive cells exhibited significant improvement greater membrane infiltration capacities ( $t=-9.577, \mathrm{P}=0.001$ ) (Figure 2.10). A similar observation was also made for pcDNA3.1-Apelin trasnfected cells and controls $(t=-5.142, P=0.007)$. Meanwhile, SAHA treated cells exhibited grater apoptosis relative to the controls $((15.100 \pm 3.997) \%$ vs $(7.300 \pm 1.745) \%, P<0.05)$ (Figure 2.11). Strikingly, there was difference in the proportion of apoptotic cells after SAHA and Apelin-13 treatment $((14.000 \pm 3.899) \%)$ or SAHA and pcNDA3.1-Apelin treatment $((14.425 \pm 4.393) \%)$. There was no significant difference in apoptosis relative among the SAHA and SAHA+Apelin-13 and SAHA and SAHA+ pcNDA3.1-Apelin treatment groups $(t=0.342, P=0.774 ; t=0.816, P=0.446)$. Western blot assays revealed that pERK1/2, pAkt, cyclin D1 and MMP-9 cytokines as well as Apelin overexpression were associated with characteristic biological behavior of MGC-803 cells. As previously mentioned, there were four subgroups, untreated cells, Apelin-13 induced cells (incubated with a concentration of $2.5 \mu \mathrm{mol} / \mathrm{L}$ Apelin for 24 hours), mock-vector transfected cells (incubated for 24 hours after transfection with pcDNA3.1 vector) and pcDNA3.1-Apelin transfected cells (incubated for 24 hours after transfection with pcDNA3.1Apelin vector). Overall, there was no significant difference in the expression of pAkt proteins between the experimental groups and controls $(P>0.05)$. However, $p E R K 1 / 2$, cyclin D1 and MMP-9 proteins were overexpressed in MGC-803 cells after Apelin-13 treatment and pcDNA3.1-Apelin transfection $(P<0.05$, Figure 2.12). Real time RT-PCR analyses further revealed that expression of Apelin mRNA was significantly higher in pLV-puro-Apelin transfectedMGC-803 cells than the controls ( $t=-4.236, P=0.013$, Figure 3.1). Western blot analysis revealed that indeed the expression of Apelin proteins was substantially higher in pLV-puro-Apelin transfected MGC-803 cells, relative to controls ( $t=-3.833, P=0.019)$ (Figure 3.2). We established 14 gastric cancer xenografts in the nude mice through subcutaneous injection with MGC-803 cells transfected with pLV-puro-Apelin or pLV-puro. One mouse died three days after injection with pLVpuro-Apelin. Control mice did not develop tumors. Mice over-expressing apelin gradually became dull, had poor appetite till 24th day after injection. Furthermore, pLV-puro-Apelin mice displayed greater growth of the tumors from day 14 of injection with tumor cells (Figure 3.3 and Table 3.1). A maximum body weight of the mice and the mean tumor size of $2.96 \pm 0.61 \mathrm{~g}$ was observed in the mice over-expressing -Apelin, whereas the minimum body weight of the mice and the mean tumor size $(1.70 \pm 0.43 \mathrm{~g})$ was observed in the control group mice (Figure 3.4). Overall, these findings suggest that Apelin promotes proliferation of gastric cancer cells both in vitro and in vivo. MVD assay by CD34 immunolabeling assays revealed that was performed to explore the mechanism underlying the differences in neoplastic growth velocity between over-expression of Apelin promotes angiogenesis of cancer cells. Xenograft tumors overexpressing apelin displayed greater MVD $(168.833 \pm 35.078)$ relative to controls $(112.333 \pm 29.859$; $t=-2.734, P=0.021$ ) (Figure 3.5).

\section{Discussion}


Local recurrence and metastasis, the principal factors associated with poor prognosis, are regulated by numerous genes and cytokines [21, 22]. The novel relationship between angiogenesis and proliferation, metastasis as well as recurrence of tumors has prompted greater research in various factors associated with angiogenesis. In particular, VEGF signaling pathway is thought to play key roles in tumor angiogenesis. Consequently, VEGF-targeted therapy has resulted in significant benefits into the treatment of several tumors cancers such as lung and colon cancers [23, 24]. Previous works have demonstrated that VEGF signaling pathway participates in tumorigenesis and development of GC and over expression of VEGF is associated with poor prognosis of GC [23-25]. However, the clinical benefits of anti-VEGF drug in human GC have been sub-optimal [25]. Therefore, it is necessary to identify novel biomarker and new vascular therapeutic targets for GC.

Apelin is an endogenous ligand recently thought to regulate angiogenesis $[9,13,14,26]$. Previous studies have demonstrated dysregulated expression of Apelin in several human solid tumors [13, 26]. However, only few studies have evaluated the role of Apelin in tumorigenesis and progression of GC. In our study, we found that VEGF was not only over-expressed in tumor tissues, but also its expression exhibited a strong positive correlation with Apelin. We also found that over expression of Apelin or VEGF predicated poor prognosis of GC. Nevertheless, further studies are needed to evaluate any synergistic relationship between Apelin and VEFG expression in promoting angiogenesis. Feng and colleagues demonstrated that expression of Apelin in tumor tissues, rather than serum, was associated with worse clinicopathological features of tumors. In addition, expression of apelin in tissues is an independent poor prognostic factor for GC [27]. Although we found Apelin was not an independent prognostic factor, multivariate Cox regression analysis revealed that over expression of Apelin was associated with poor prognosis. In addition, the strong correlation between Apelin over-expression and late - $\mathrm{T}$ and $\mathrm{N}$ stages, as well as vessel invasion suggests that Apelin promotes local recurrence and lymph node metastasis of tumors.

RT-PCR, western blot and ELISA further revealed that both Apelin proteins and its mRNA were under expressed in MGC-803 cells. However, previous works have demonstrated that Apelin proteins and its mRNA are expressed differently in colon adenocarcinomas [28]. A similar observation was made for human non-small lung cancer [15]. MGC-803 cell line is poorly differentiated, HGC-27 cell line is undifferentiated whereas SGC-7901 cell line exhibits metastatic properties. These distinct features have been linked to the differential expression of Apelin in the cells.

In the present study, we used the MGC-803 cell line. Overall, RT-PCR, western blot and ELISA analyses revealed that Apelin was over-expressed in MGC-803 cells transfected with pcDNA3.1-Apelin. The findings suggested that Apelin expressed in cancer cells function in paracrine and autocrine manner. Furthermore, we found that both over-expressed exogenous and endogenous Apelin substantially modulated the proliferation and migration of MGC-803 cells. Previous studies have demonstrated that exogenous Apelin can enhance proliferation and migration of cancer cells such as lung adenocarcinomas cell line A549 [29] and human prostate cancer cell line LNCaP [30]. Moreover, hepatocellular carcinoma cell (HepG2) [16] and vascular smooth muscle cells (VSMCs) [31] over expressing apelin were resistant to apoptosis. Even 
though the effects of Apelin overexpression on the proliferation of colorectal cancer cells have not been reported, over-expression of apelin promotes proliferation of xenograft tumors in mice [28].

SAHA, a member of histone deacetylase inhibitor, induces apoptosis in MGC-803 cells [20]. To our knowledge, the relationship between overexpression of Apelin and malignant biological behavior of human GC cells both in vitro and in vivo has not been reported. In this study, we found SAHA had no effect onMGC-803 cells transfected with pcDNA3.1-Apelin or treated with exogenous Apelin.

Studies shows that both mitogen-activated protein kinase kinase/(MAPK)/ERK and phosphoinositide 3kinase (PI3K)/Akt signaling pathways regulate the proliferation, migration, angiogenesis and inhibition of apoptosis of tumor cells, including the human GC cells [32,33]. Tumor cells promote ERK phosphorylation, inducing transcription of cyclin D1 that mainly promote growth of tumor cells via the ERK signaling pathway. Cyclin D1 promotes transition of cells from G1 to $S$ phase and proliferation of cells [34]. Both MAPK/ERK and PI3K/Akt signaling pathways regulate invasion and metastasis of cancer cells primarily by up-regulating MMP-9 transcription $[35,36]$. The apoptosis is inhibited by the expression of Bcl-2 family regulated via the MAPK/ERK and PI3K/Akt signaling pathway or inhibition of the caspase signaling pathway.

Our findings demonstrated that the expression of phosphorylated ERK (pERK), cyclin D1 associated with cell proliferation and MMP-9 linked to invasion of cancer cells were all over-expressed following Apelin treatment. Strikingly, there was no significant difference in the expression of pAkt between treatment and control groups. Apelin/APJ signaling pathway regulates apoptosis of cells through phosphorylation of Apelin [28]. MG132 is a proteasome inhibitor, which participates in inducing apoptosis of cells by downregulating the expression of pAkt in multiple tumor cells [37]. Apelin/APJ modulates apoptosis of colorectal cancer cells by inducing phosphorylation of Akt [28]. Remarkably, exogenous Apelin neither promoted nor modulated the expression of pERK in LoVo cells [28]. Yang et al. reported that Apelin-13 induces cell proliferation and promotes autophagy through phosphorylation of ERK. Phosphorylated ERK intern activates downstream transduction cascades in human lung cancer cell line A549 [29]. Moreover, exogenous Apelin promotes migration and inhibits apoptosis of cancer cells but not proliferation of cancer cells by inducing phosphorylation of ERK and Akt in human lymphatic endothelial cells [31].

On the other hand, Apelin had no effect on apoptosis in vitro induced by SAHA and phosphorylated Akt. There relationship between SAHA and the MAPK/ERK and PI3K/Akt signaling pathways is not straightforward. Apelin regulated apoptosis of GC cells via the MAPK/ERK signaling pathway. Therefore, further studies should be conducted to unravel the relationship between Apelin and SAHA expression. Notably, we observed a positive feedback between Apelin expression and ERK activation. Nevertheless, we did not down-regulate Apelin expression in the HGC-27 GC cell lines for lack of an effective SiRNA.

To the best of our knowledge, this is the first study to establish human GC cell xenograft models overexpressing Apelin. Overall our findings suggest that Apelin overexpression promotes growth and angiogenesis of human GC cells in vivo. Apelin is an angiogenic factor that stimulates proliferation and migration of vascular endothelial cells through extrinsic and intrinsic pathways. In addition, Apelin or APJ 
knockdown efficiently blocks angiogenesis [38]. Sorli et al. revealed that Apelin overexpression increased the formation of tumorous vessels and accelerated tumor growth and tumor neoangiogenesis in paracrine manner [39]. Kidoya et al. demonstrated that the Apelin/APJ signaling pathway regulates maturation and function of tumor vascular system [40]. MVD is the gold standard for estimating tumor angiogenesis, closely associated with tumor invasion and metastasis and is an independent prognosis factor for GC [39]. Berta et al. observed that Apelin overexpression stimulates tumor growth and increase MVD and capillary diameter [15]. Apelin-13 antagonist blocks tumor proliferation or angiogenic activity of hepatocellular carcinoma xenograft model, validating the role of Apelin overexpression in tumourigenesis through angiogenesis [41]. Overall, overexpression of Apelin promotes proliferation of tumor cells, while simultaneously enhancing the MVD.

\section{Conclusion}

In general, compared to normal adjacent cells, human gastric cancer tissues over-express apelin. The over-expression of Apelin is associated with vessel invasion, $\mathrm{N}$ and $\mathrm{T}$ tumor stage, expression of VEGF and high MVD. These factors are intern associated with poor prognosis of GC. Overall, over-expression of Apelin promotes proliferation and invasion of cancer cells via the ERK/Cyclin D1/MMP-9 signaling pathway. However, it does not inhibit SAHA-induced apoptosi of cancer cells (MGC-803 cell line). Moreover, high Apelin levels enhance angiogenesis of subcutaneous xenograft. Given that occurrence and development of cancers are closely linked to angiogenesis, Apelin antagonist can be a novel therapeutic target for human GC.

\section{Abbreviations}

Gc: Gastric cancer, RT-PCR: real-time reverse transcription-polymerase chain reaction, VEGF: vascular endothelial growth factor, CT: computed tomography, IMRT: intensive modulation radiotherapy, PFS: progression-free survival, OS: Overall survival, SDS: sodium dodecyl sulfate, MVD: Microvessel densities, PVDF: polyvinylidene fluoride, TBS: Tris-buffered saline, HRP: horseradish peroxidase, DMSO: dimethyl sulfoxide, SAHA: Suberoylanilide hydroxamic acid, HDACl: histone deacetylase inhibitor, MAPK: mitogenactivated protein kinase kinase, P13K: phosphoinositide 3-kinase.

\section{Declarations}

\section{Ethics approval and consent to participate}

All procedures in study involving human participants were performed in accordance with the institutional ethical standards and in line with the national research committee and the 1964 Helsinki declaration.

\section{Consent for publication}

All participants consented to this study. 
Availability of data and materials

The data used or analyzed in this study are available subject on reasonable request.

\section{Competing interests}

The authors declare no conflicts of interest.

\section{Funding}

This work was supported by research fund of Binzhou Medical College Affiliated Hospital Foundation (BY2018KJ10). The funding body plays no role in the design of the study, collection, analysis, interpretation of data or in writing the manuscript.

\section{Authors' contributions}

LJT: Conceptualization, Methodology, Formal analysis and Writing - Original Draft; HZL: Software, Data analysis and Data Curation; QZ: Investigation and Resources. DZG: Validation.

JY: Visualization.

HTG: Data analysis.

YJZ: Investigation.

YQH: Project administration.

YZH: Writing - Review \& Editing and Supervision.

All authors are accountable for all aspects of the work.

\section{Acknowledgements}

We thank all patients who participated in this study.

\section{References}

1. Torre LA, Bray F, Siegel RL, Ferlay J, Lortet-Tieulent J, Jemal A: Global cancer statistics, 2012. CA Cancer J Clin 2015, 65(2):87-108.

2. Ferlay J, Soerjomataram I, Dikshit R, Eser S, Mathers C, Rebelo M, Parkin DM, Forman D, Bray F: Cancer incidence and mortality worldwide: sources, methods and major patterns in GLOBOCAN 2012. Int J Cancer 2015, 136(5):E359-386.

3. Msika S, Tazi MA, Benhamiche AM, Couillault C, Harb M, Faivre J: Population-based study of diagnosis, treatment and prognosis of gastric cancer. Br J Surg 1997, 84(10):1474-1478. 
4. Zhang XF, Huang CM, Lu HS, Wu XY, Wang C, Guang GX, Zhang JZ, Zheng CH: Surgical treatment and prognosis of gastric cancer in 2,613 patients. World J Gastroenterol 2004, 10(23):3405-3408.

5. Shen W, Li J, Cui J, Xi H, Liu S, Wei B, Chen L: [Meta-analysis of prognosis after surgical treatment in gastric cancer patients with liver metastasis]. Zhonghua Wei Chang Wai Ke Za Zhi 2014, 17(2):128132.

6. Bian Y, Wang Z, Xu J, Zhao W, Cao H, Zhang Z: Elevated Rictor expression is associated with tumor progression and poor prognosis in patients with gastric cancer. Biochem Biophys Res Commun 2015, 464(2):534-540.

7. Liu H, Zhang Y, Hao X, Kong F, Li X, Yu J, Jia Y: GPRC5A overexpression predicted advanced biological behaviors and poor prognosis in patients with gastric cancer. Tumour Biol 2016, 37(1):503-510.

8. Tatemoto K, Hosoya M, Habata Y, Fujii R, Kakegawa T, Zou MX, Kawamata Y, Fukusumi S, Hinuma S, Kitada $\mathrm{C}$ et al: Isolation and characterization of a novel endogenous peptide ligand for the human APJ receptor. Biochem Biophys Res Commun 1998, 251(2):471-476.

9. Claesson-Welsh L: What is normal? Apelin and VEGFA, drivers of tumor vessel abnormality. EMBO Mol Med 2019, 11(8):e10892.

10. Chen MM, Ashley EA, Deng DX, Tsalenko A, Deng A, Tabibiazar R, Ben-Dor A, Fenster B, Yang E, King JY et al: Novel role for the potent endogenous inotrope apelin in human cardiac dysfunction. Circulation 2003, 108(12):1432-1439.

11. Kowanetz M, Ferrara N: Vascular endothelial growth factor signaling pathways: therapeutic perspective. Clin Cancer Res 2006, 12(17):5018-5022.

12. Waldner MJ, Wirtz S, Jefremow A, Warntjen M, Neufert C, Atreya R, Becker C, Weigmann B, Vieth M, Rose-John $S$ et al: VEGF receptor signaling links inflammation and tumorigenesis in colitisassociated cancer. J Exp Med 2010, 207(13):2855-2868.

13. Sorli SC, Le Gonidec S, Knibiehler B, Audigier Y: Apelin is a potent activator of tumour neoangiogenesis. Oncogene 2007, 26(55):7692-7699.

14. Sorli SC, van den Berghe L, Masri B, Knibiehler B, Audigier Y: Therapeutic potential of interfering with apelin signalling. Drug Discov Today 2006, 11(23-24):1100-1106.

15. Berta J, Kenessey I, Dobos J, Tovari J, Klepetko W, Jan Ankersmit H, Hegedus B, Renyi-Vamos F, Varga J, Lorincz Z et al: Apelin expression in human non-small cell lung cancer: role in angiogenesis and prognosis. J Thorac Oncol 2010, 5(8):1120-1129.

16. Heo K, Kim YH, Sung HJ, Li HY, Yoo CW, Kim JY, Park JY, Lee UL, Nam BH, Kim EO et al: Hypoxiainduced up-regulation of apelin is associated with a poor prognosis in oral squamous cell carcinoma patients. Oral Oncol 2012, 48(6):500-506.

17. Tovari J, Gilly R, Raso E, Paku S, Bereczky B, Varga N, Vago A, Timar J: Recombinant human erythropoietin alpha targets intratumoral blood vessels, improving chemotherapy in human xenograft models. Cancer Res 2005, 65(16):7186-7193. 
18. Livak KJ, Schmittgen TD: Analysis of relative gene expression data using real-time quantitative PCR and the 2(-Delta Delta C(T)) Method. Methods 2001, 25(4):402-408.

19. Masri B, Morin N, Pedebernade L, Knibiehler B, Audigier Y: The apelin receptor is coupled to Gi1 or Gi2 protein and is differentially desensitized by apelin fragments. J Biol Chem 2006, 281(27):1831718326.

20. Lu H, Yang XF, Tian XQ, Tang SL, Li LQ, Zhao S, Zheng HC: The in vitro and vivo anti-tumor effects and molecular mechanisms of suberoylanilide hydroxamic acid (SAHA) and MG132 on the aggressive phenotypes of gastric cancer cells. Oncotarget 2016, 7(35):56508-56525.

21. Zang ZJ, Cutcutache I, Poon SL, Zhang SL, McPherson JR, Tao J, Rajasegaran V, Heng HL, Deng N, Gan A et al: Exome sequencing of gastric adenocarcinoma identifies recurrent somatic mutations in cell adhesion and chromatin remodeling genes. Nat Genet 2012, 44(5):570-574.

22. Oltean S, Bates DO: Hallmarks of alternative splicing in cancer. Oncogene 2014, 33(46):5311-5318.

23. Giaccone G: The potential of antiangiogenic therapy in non-small cell lung cancer. Clin Cancer Res 2007, 13(7):1961-1970.

24. Tabernero J, Yoshino T, Cohn AL, Obermannova R, Bodoky G, Garcia-Carbonero R, Ciuleanu TE, Portnoy DC, Van Cutsem E, Grothey A et al: Ramucirumab versus placebo in combination with second-line FOLFIRI in patients with metastatic colorectal carcinoma that progressed during or after first-line therapy with bevacizumab, oxaliplatin, and a fluoropyrimidine (RAISE): a randomised, double-blind, multicentre, phase 3 study. Lancet Oncol 2015, 16(5):499-508.

25. Van Cutsem E, de Haas S, Kang YK, Ohtsu A, Tebbutt NC, Ming Xu J, Peng Yong W, Langer B, Delmar $\mathrm{P}$, Scherer SJ et al: Bevacizumab in combination with chemotherapy as first-line therapy in advanced gastric cancer: a biomarker evaluation from the AVAGAST randomized phase III trial. J Clin Oncol 2012, 30(17):2119-2127.

26. Amir E, Mandoky L, Blackhall F, Thatcher N, Klepetko W, Ankersmit HJ, Reza Hoda MA, Ostoros G, Dank M, Dome B: Antivascular agents for non-small-cell lung cancer: current status and future directions. Expert Opin Investig Drugs 2009, 18(11):1667-1686.

27. Feng $M$, Yao G, Yu H, Qing Y, Wang K: Tumor apelin, not serum apelin, is associated with the clinical features and prognosis of gastric cancer. BMC Cancer 2016, 16(1):794.

28. Picault FX, Chaves-Almagro C, Projetti F, Prats H, Masri B, Audigier Y: Tumour co-expression of apelin and its receptor is the basis of an autocrine loop involved in the growth of colon adenocarcinomas. Eur J Cancer 2014, 50(3):663-674.

29. Yang L, Su T, Lv D, Xie F, Liu W, Cao J, Sheikh IA, Qin X, Li L, Chen L: ERK1/2 mediates lung adenocarcinoma cell proliferation and autophagy induced by apelin-13. Acta Biochim Biophys Sin (Shanghai) 2014, 46(2):100-111.

30. Wan Y, Zeng ZC, Xi M, Wan S, Hua W, Liu YL, Zhou YL, Luo HW, Jiang FN, Zhong WD: Dysregulated microRNA-224/apelin axis associated with aggressive progression and poor prognosis in patients with prostate cancer. Hum Pathol 2015, 46(2):295-303. 
31. Cui RR, Mao DA, Yi L, Wang C, Zhang XX, Xie H, Wu XP, Liao XB, Zhou H, Meng JC et al: Apelin suppresses apoptosis of human vascular smooth muscle cells via APJ/PI3-K/Akt signaling pathways. Amino Acids 2010, 39(5):1193-1200.

32. Gala K, Chandarlapaty S: Molecular pathways: HER3 targeted therapy. Clin Cancer Res 2014, 20(6):1410-1416.

33. Shen C, Song YH, Xie Y, Wang X, Wang Y, Wang C, Liu S, Xue SL, Li Y, Liu B et al: Downregulation of HADH promotes gastric cancer progression via Akt signaling pathway. Oncotarget 2017, 8(44):76279-76289.

34. Musgrove EA, Caldon CE, Barraclough J, Stone A, Sutherland RL: Cyclin D as a therapeutic target in cancer. Nat Rev Cancer 2011, 11(8):558-572.

35. Kang MH, Kim JS, Seo JE, Oh SC, Yoo YA: BMP2 accelerates the motility and invasiveness of gastric cancer cells via activation of the phosphatidylinositol 3-kinase (PI3K)/Akt pathway. Exp Cell Res 2010, 316(1):24-37.

36. Han J, Xie Y, Lan F, Yu Y, Liu W, Chen J, Zheng F, Ouyang X, Lin X, Lin Y et al: Additive effects of EGF and IL-1beta regulate tumor cell migration and invasion in gastric adenocarcinoma via activation of ERK1/2. Int J Oncol 2014, 45(1):291-301.

37. Yu C, Friday BB, Lai JP, Yang L, Sarkaria J, Kay NE, Carter CA, Roberts LR, Kaufmann SH, Adjei AA: Cytotoxic synergy between the multikinase inhibitor sorafenib and the proteasome inhibitor bortezomib in vitro: induction of apoptosis through Akt and c-Jun NH2-terminal kinase pathways. Mol Cancer Ther 2006, 5(9):2378-2387.

38. Lv D, Li H, Chen L: Apelin and APJ, a novel critical factor and therapeutic target for atherosclerosis. Acta Biochim Biophys Sin (Shanghai) 2013, 45(7):527-533.

39. Kalin RE, Kretz MP, Meyer AM, Kispert A, Heppner FL, Brandli AW: Paracrine and autocrine mechanisms of apelin signaling govern embryonic and tumor angiogenesis. Dev Biol 2007, 305(2):599-614.

40. Kidoya H, Kunii N, Naito H, Muramatsu F, Okamoto Y, Nakayama T, Takakura N: The apelin/APJ system induces maturation of the tumor vasculature and improves the efficiency of immune therapy. Oncogene 2012, 31(27):3254-3264.

41. Muto J, Shirabe K, Yoshizumi T, Ikegami T, Aishima S, Ishigami K, Yonemitsu Y, Ikeda T, Soejima Y, Maehara Y: The apelin-APJ system induces tumor arteriogenesis in hepatocellular carcinoma. Anticancer Res 2014, 34(10):5313-5320.

\section{Tables}

Table 1.1 Expression of Apelin and VEGF in gastric cancer tissues and adjacent tissues 


\begin{tabular}{|c|c|c|c|c|c|}
\hline & & cancer tissues & adjacent tissues & $\chi^{2}$ value & $P$ value \\
\hline \multirow[t]{2}{*}{ Apelin } & positive & 88 & 53 & \multirow[t]{2}{*}{14.386} & \multirow[t]{2}{*}{$\otimes 0.001$} \\
\hline & negative & 90 & 125 & & \\
\hline \multirow[t]{2}{*}{ VEGF } & positive & 99 & 71 & \multirow[t]{2}{*}{8.827} & \multirow[t]{2}{*}{0.003} \\
\hline & negative & 79 & 107 & & \\
\hline
\end{tabular}

Table 1.2 The relationship between Apelin and VEGF and clinicopathologic factors 


\begin{tabular}{|c|c|c|c|c|c|c|c|c|}
\hline \multirow[t]{2}{*}{ Characteristics } & \multicolumn{2}{|c|}{ Apelin } & \multirow{2}{*}{$\begin{array}{l}x^{2} \\
\text { value }\end{array}$} & \multirow{2}{*}{$\begin{array}{l}P \\
\text { value }\end{array}$} & \multicolumn{2}{|c|}{ VEGF } & \multirow{2}{*}{$\begin{array}{l}\chi^{2} \\
\text { value }\end{array}$} & \multirow{2}{*}{$\begin{array}{l}P \\
\text { value }\end{array}$} \\
\hline & 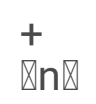 & 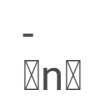 & & & 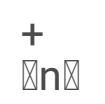 & $\overline{\nabla n} \rrbracket$ & & \\
\hline Gender & & & 1.001 & 0.317 & & & 0.810 & 0.368 \\
\hline Male & 67 & 74 & & & 76 & 65 & & \\
\hline Female & 21 & 16 & & & 23 & 14 & & \\
\hline Age『years $\rrbracket$ & & & 0.840 & 0.772 & & & 1.585 & 0.208 \\
\hline$\leq 62$ & 46 & 49 & & & 57 & 38 & & \\
\hline$\nabla 62$ & 42 & 41 & & & 42 & 41 & & \\
\hline site of primary lesion & & & 3.240 & 0.356 & & & 6.420 & 0.093 \\
\hline Cardia & 28 & 33 & & & 26 & 35 & & \\
\hline Fundus & 7 & 7 & & & 9 & 5 & & \\
\hline Body & 21 & 28 & & & 31 & 18 & & \\
\hline Antrum & 32 & 22 & & & 33 & 21 & & \\
\hline Pathological differentiation & & & 11.240 & 0.024 & & & 5.103 & 0.277 \\
\hline $\begin{array}{l}\text { Well or moderately } \\
\text { differentiated }\end{array}$ & 33 & 49 & & & 43 & 39 & & \\
\hline Poorly differentiated & 42 & 33 & & & 42 & 33 & & \\
\hline Mucinous adenocarcinoma & 11 & 6 & & & 10 & 7 & & \\
\hline Signet ring cell carcinoma & 0 & 2 & & & 2 & 0 & & \\
\hline Other & 2 & 0 & & & 2 & 0 & & \\
\hline Nerve invasion & & & 5.731 & 0.017 & & & 3.116 & 0.078 \\
\hline Yes & 49 & 34 & & & 52 & 31 & & \\
\hline No & 39 & 56 & & & 47 & 48 & & \\
\hline Vessel invasion & & & 7.910 & 0.005 & & & 5.807 & 0.016 \\
\hline Yes & 38 & 21 & & & 40 & 19 & & \\
\hline No & 50 & 69 & & & 59 & 60 & & \\
\hline T stage & & & 9.845 & 0.020 & & & 11.597 & 0.009 \\
\hline T1 & 1 & 1 & & & 1 & 1 & & \\
\hline $\mathrm{T} 2$ & 2 & 11 & & & 3 & 10 & & \\
\hline
\end{tabular}




\begin{tabular}{|c|c|c|c|c|c|c|c|c|}
\hline T3 & 58 & 63 & & & 64 & 57 & & \\
\hline $\mathrm{T} 4$ & 27 & 15 & & & 31 & 11 & & \\
\hline $\mathrm{N}$ stage & & & 14.433 & 0.002 & & & 8.653 & 0.034 \\
\hline NO & 18 & 23 & & & 21 & 20 & & \\
\hline $\mathrm{N} 1$ & 13 & 26 & & & 16 & 23 & & \\
\hline $\mathrm{N} 2$ & 22 & 27 & & & 35 & 14 & & \\
\hline N3 & 35 & 14 & & & 27 & 22 & & \\
\hline
\end{tabular}

Table 1.3 The relationship between the expression of Apelin, VEGF and MVD

\begin{tabular}{|lllll|}
\hline \multicolumn{2}{|l}{ Characteristics } & MVD & $t$ & $P$ \\
\hline \multirow{2}{*}{ Apelin } & positive & $33.086 \pm 7.862$ & 2.917 & 0.013 \\
\cline { 2 - 3 } & negative & $21.071 \pm 6.320$ & & \\
\cline { 1 - 3 } VEGF & positive & $29.075 \pm 8.193$ & 2.514 & 0.025 \\
\cline { 2 - 3 } & negative & $19.638 \pm 5.614$ & & \\
\hline
\end{tabular}

Table 1.4 The association between Apelin and VEGF expression

\begin{tabular}{|llllll|}
\hline Characteristics & Apelin & & $r_{s}$ & $P$ \\
\hline & & positive & negative & 0.856 & 0.004 \\
\multirow{2}{*}{ VEGF } & positive & 64 & 35 & & \\
\cline { 2 - 4 } & negative & 24 & 55 & & \\
\hline
\end{tabular}

Table 1.5 COX univariate analysis of factors associated with survival in 178 patients with gastric cancer 


\begin{tabular}{|c|c|c|c|}
\hline \multirow[t]{2}{*}{ Characteristics } & \multicolumn{3}{|c|}{5 years overall survival $\mathbb{X} \mathrm{OS} \rrbracket$} \\
\hline & $\mathrm{HR}$ & $95 \% \mathrm{Cl}$ & $P$ value \\
\hline Age $\Downarrow$ years $\rrbracket$ & & & 0.451 \\
\hline$\leq 62$ & 1.000 & Ref. & \\
\hline$>62$ & 1.284 & $0.786-1.852$ & \\
\hline Gender & & & 0.423 \\
\hline Male & 1.000 & Ref. & \\
\hline Female & 0.936 & $0.605-1.633$ & \\
\hline \multicolumn{4}{|l|}{ Position } \\
\hline Cardia & 1.000 & Ref. & - \\
\hline Fundus & 0.972 & $0.112-6.668$ & 0.503 \\
\hline Corpora & 0.774 & $0.276-1.942$ & 0.137 \\
\hline Sinuses & 0.865 & $0.413-1.826$ & 0.257 \\
\hline \multicolumn{4}{|l|}{ Pathological differentiation } \\
\hline Well/moderately differentiated & 1.000 & Ref. & - \\
\hline Poorly differentiated & 2.336 & $1.324-3.735$ & 0.030 \\
\hline Other ${ }^{a}$ & 4.413 & $1.041-12.546$ & $\otimes 0.001$ \\
\hline Nerve invasion & & & 0.068 \\
\hline No & 1.000 & Ref. & \\
\hline Yes & 1.258 & $0.646-2.425$ & \\
\hline Vessel invasion & & & 0.025 \\
\hline No & 1.000 & Ref. & \\
\hline Yes & 2.369 & $0.983-4.337$ & \\
\hline T stages & & & 0.016 \\
\hline $\mathrm{T} 1+\mathrm{T} 2$ & 1.000 & Ref. & \\
\hline $\mathrm{T} 3+\mathrm{T} 4$ & 3.007 & $1.353-5.724$ & \\
\hline $\mathrm{N}$ stages & & & $\bowtie 0.001$ \\
\hline NO & 1.000 & Ref. & \\
\hline $\mathrm{N}+{ }^{\mathrm{b}}$ & 4.591 & $2.081-8.852$ & \\
\hline
\end{tabular}




\begin{tabular}{|llll|} 
Apelin & & & 0.001 \\
Negative & 1.000 & Ref. & \\
\cline { 1 - 4 } Positive & 3.984 & $1.276-6.824$ & \\
VEGF & & & 0.027 \\
Negative & 1.000 & Ref. & \\
Positive & 2.322 & $1.020-5.316$ & \\
\hline
\end{tabular}

a: Mucinous adenocarcinoma, signet ring cell carcinoma and small cell carcinoma. $b \llbracket N_{1} \square N_{2} \square N_{3}$

Table 1.6 Multivariable analysis of the factors associated with survival in 178 patients with gastric cancer 


\begin{tabular}{|c|c|c|c|}
\hline \multirow[t]{2}{*}{ Characteristics } & \multicolumn{3}{|c|}{ 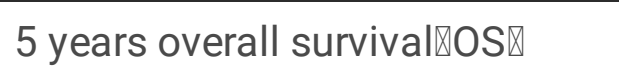 } \\
\hline & $\mathrm{HR}$ & $95 \% \mathrm{Cl}$ & $P$ value \\
\hline Apelin & & & 0.095 \\
\hline Negative & 1.000 & Ref. & \\
\hline Positive & 1.226 & $0.559-2.673$ & \\
\hline VEGF & & & 0.139 \\
\hline Negative & 1.000 & Ref. & \\
\hline Positive & 1.178 & $0.420-2.569$ & \\
\hline \multicolumn{4}{|l|}{ Pathological differentiation } \\
\hline Well/ moderately differentiated & 1.000 & Ref. & - \\
\hline Poorly differentiated & 2.605 & $1.228-4.947$ & 0.027 \\
\hline Other ${ }^{a}$ & 3.239 & $1.153-10.345$ & 0.012 \\
\hline Vessel invasion & & & 0.069 \\
\hline No & 1.000 & Ref. & \\
\hline Yes & 1.427 & $0.698-3.566$ & \\
\hline T stages & & & 0.008 \\
\hline $\mathrm{T} 1+\mathrm{T} 2$ & 1.000 & Ref. & \\
\hline $\mathrm{T} 3+\mathrm{T} 4$ & 3.225 & $1.547-6.035$ & \\
\hline $\mathrm{N}$ stages & & & $₫ 0.001$ \\
\hline NO & 1.000 & Ref. & \\
\hline$N++^{b}$ & 3.987 & $1.836-8.148$ & \\
\hline
\end{tabular}

a: Mucinous adenocarcinoma, signet ring cell carcinoma and small cell carcinoma. $b \square N_{1} \square N_{2} \square N_{3}$ Table 3.1 The volume of gastric cancer xenografts in nude mice and statistical analysis 


\begin{tabular}{|lllrl|}
\hline Time(day) & Control $( \pm \mathrm{s})$ & Overexpression of Apelin $( \pm \mathrm{s})$ & $t$ value & $P$ value \\
\hline 7 & $22.656 \pm 8.702$ & $26.775 \pm 11.745$ & -0.630 & 0.543 \\
\hline 10 & $61.517 \pm 23.151$ & $80.836 \pm 26.352$ & -1.232 & 0.246 \\
\hline 14 & $106.115 \pm 36.515$ & $196.010 \pm 66.854$ & -2.639 & 0.025 \\
\hline 17 & $306.789 \pm 105.315$ & $567.346 \pm 198.854$ & -2.598 & 0.027 \\
\hline 21 & $748.919 \pm 214.059$ & $1399.063 \pm 499.872$ & -2.673 & 0.023 \\
\hline 24 & $1367.348 \pm 444.701$ & $2557.645 \pm 684.409$ & -3.261 & 0.009 \\
\hline
\end{tabular}

\section{Figures}

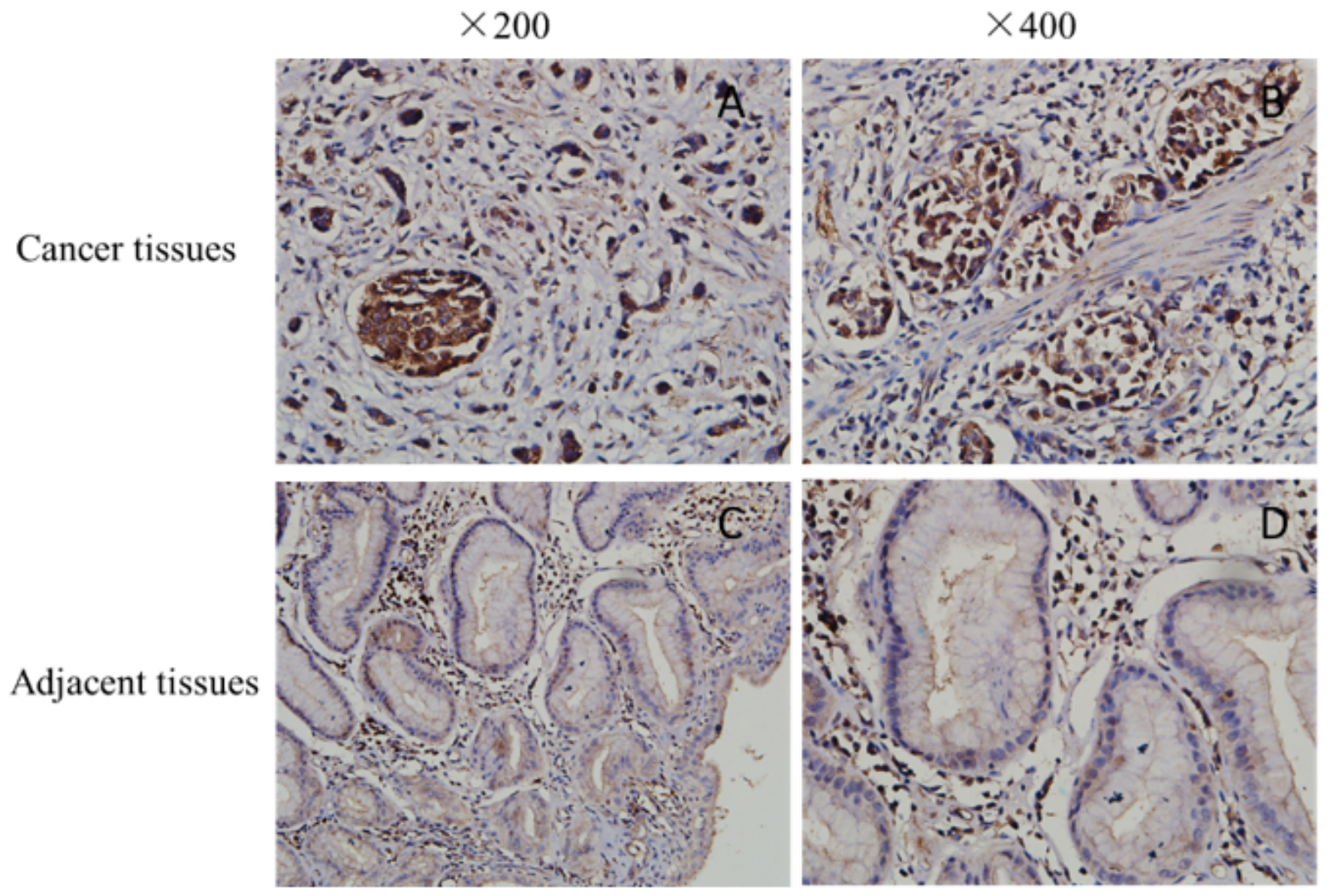

\section{Figure 1}

Immunohistochemical staining for Apelin in gastric cancer tissues (A, B) and adjacent normal tissues (C, D) (corresponding to low and high Apelin expression, respectively) Magnification, $\times 200(A, C), \times 400(B, D)$. 


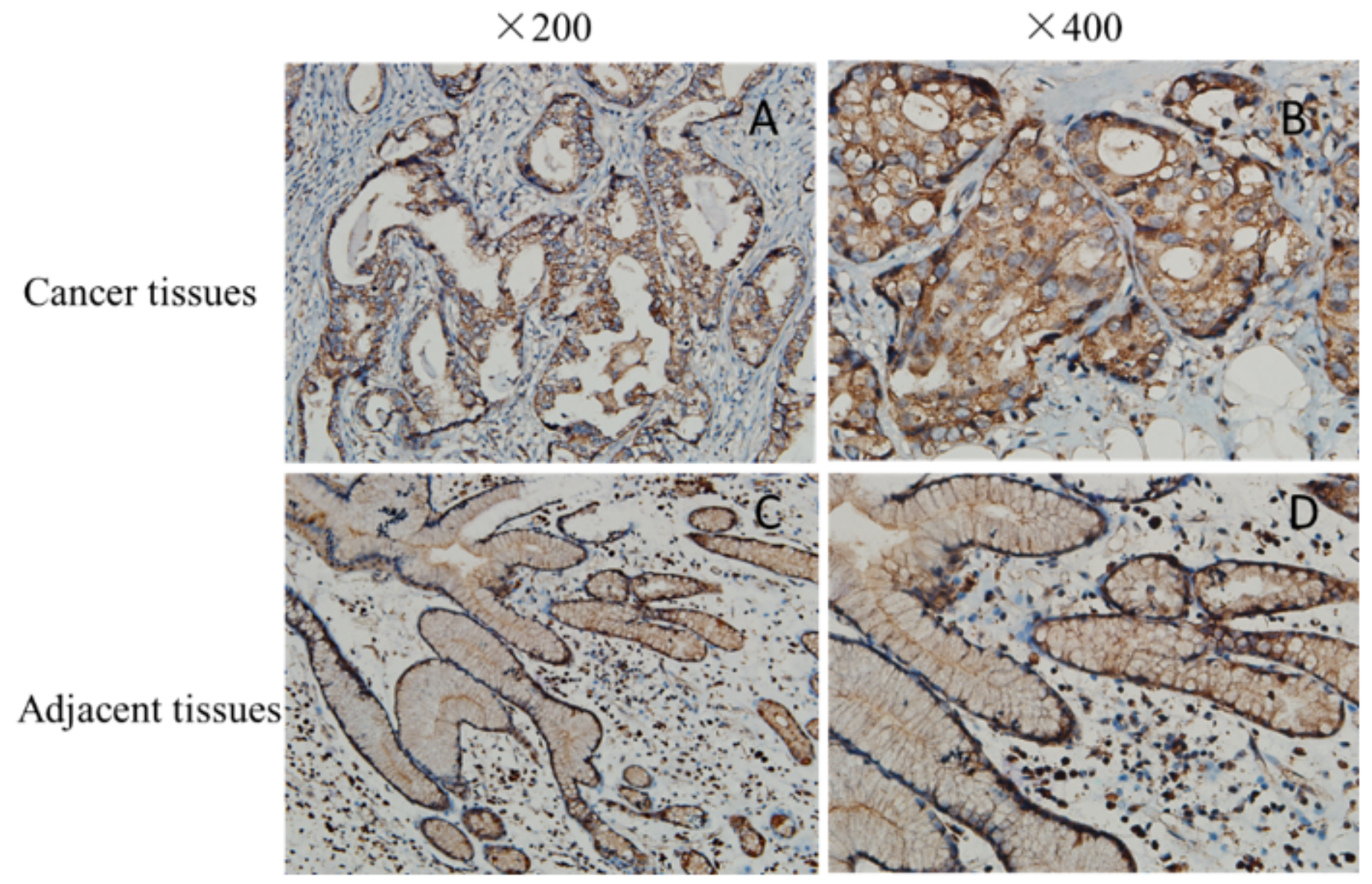

Figure 2

Immunohistochemical staining for VEGF in gastric cancer tissues $(A, B)$ and adjacent normal tissues (C, D) (corresponding to low and high VEGF expression, respectively) Magnification, $\times 200(A, C), \times 400(B, D)$. 


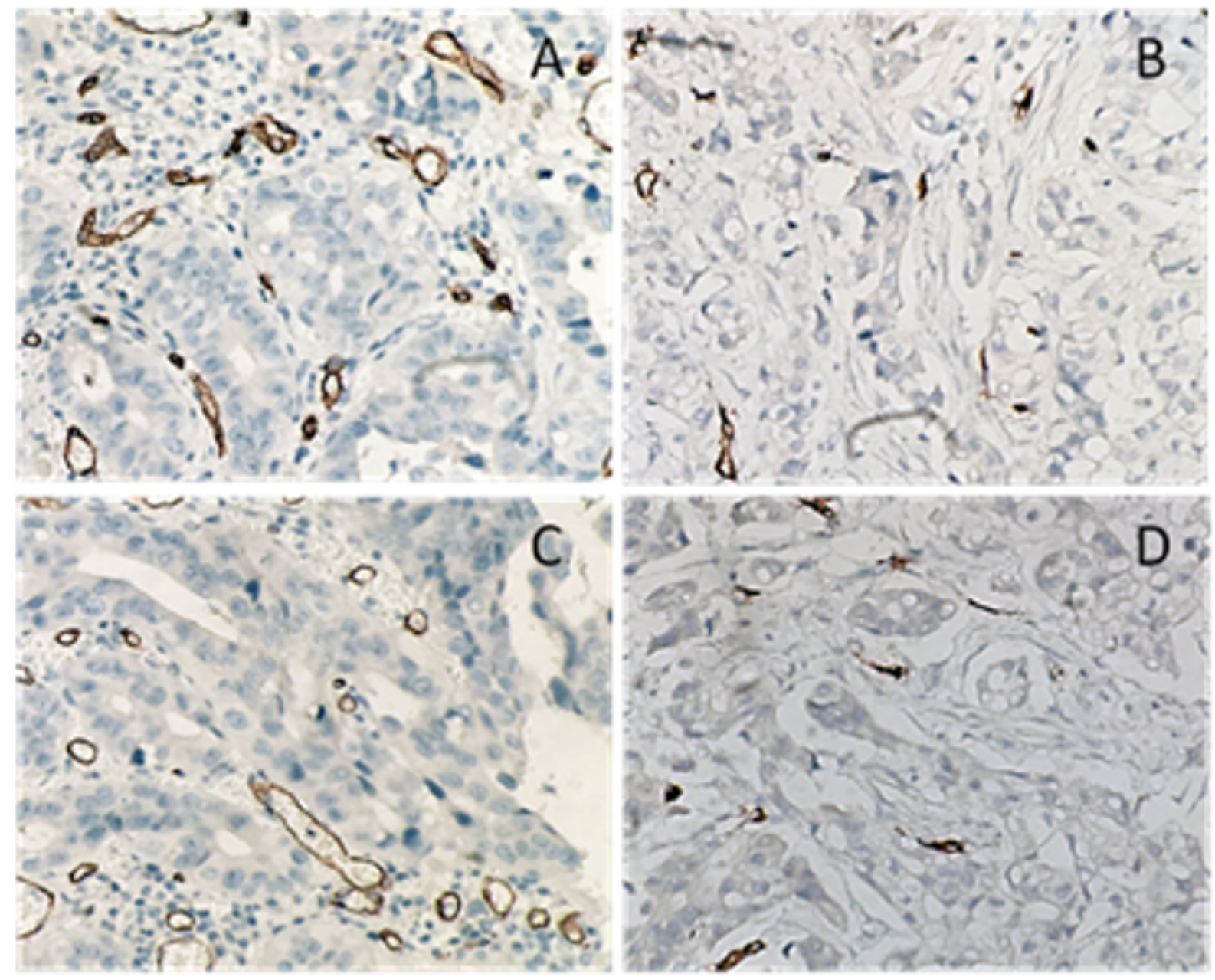

Figure 3

Immunohistochemical staining for MVD in gastric cancer tissues. A: Apelin-positive subgroup accompanied with high MVD expression; B: Apelin-negative subgroup accompanied with low MVD expression; C: VEGF-positive subgroup accompanied with high MVD expression; D: VEGF-negative subgroup accompanied with low MVD expression; Magnification×200 ) 


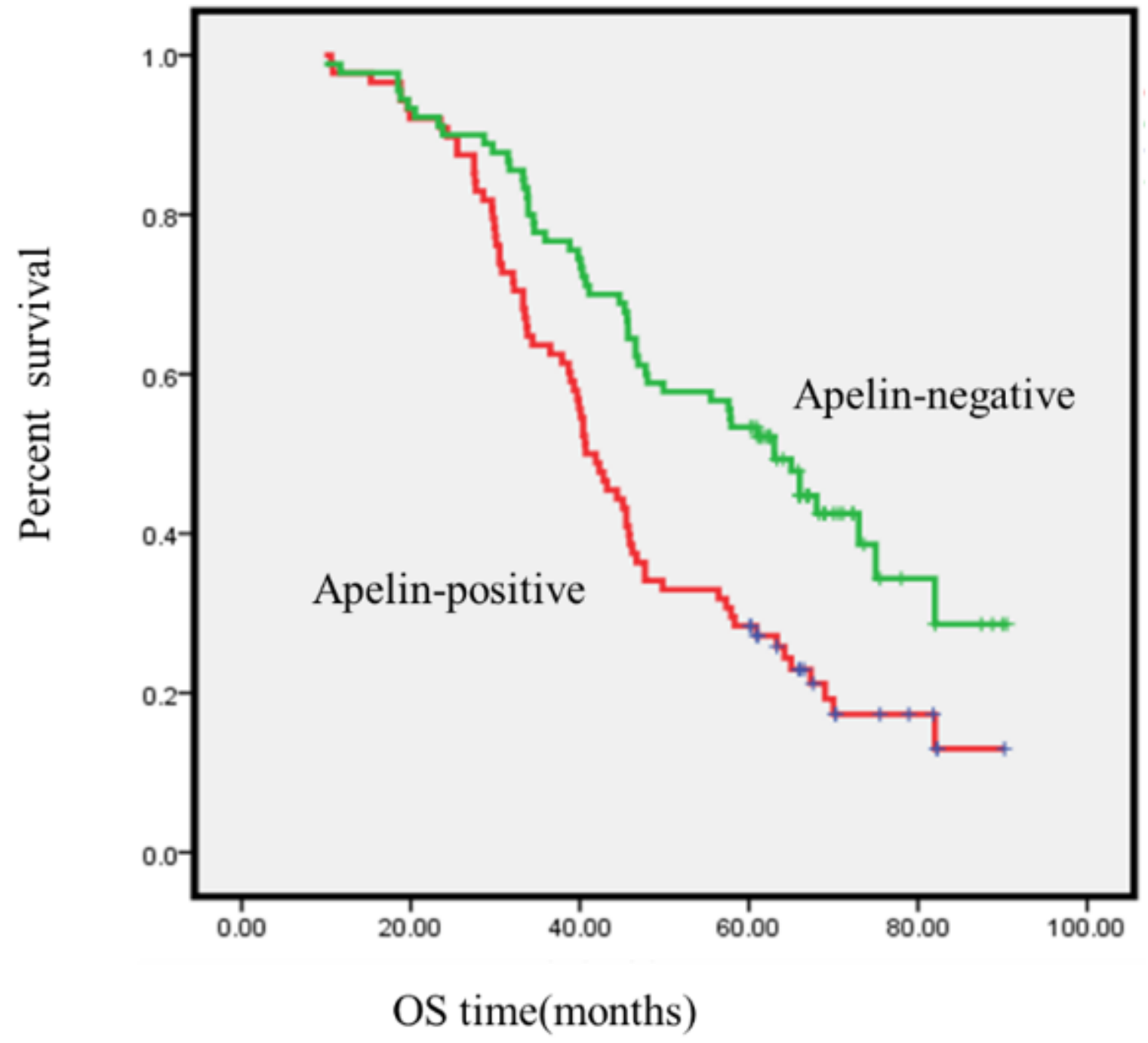

Figure 4

Kaplan-Meier curves for 178 patients diagnosed with GC in relation to Apelin expression. Patients of Apelin-negative subgroup had significantly longer OS period (60.2 months) compared with those of Apelin-negative (40.7 months). 


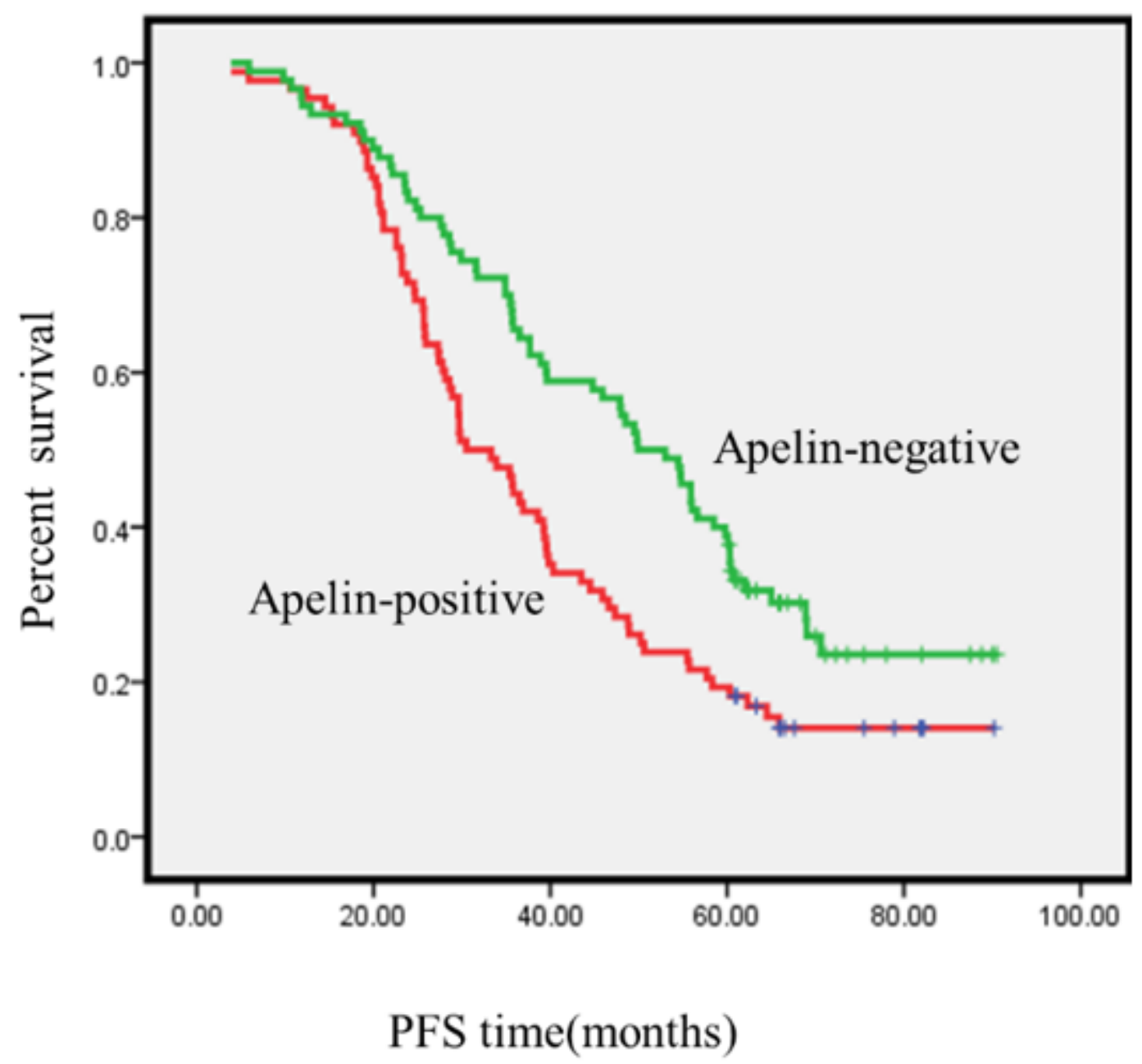

Figure 5

Kaplan-Meier curves for the PFS of 178 patients diagnosed with GC in relation to Apelin expression. Patients of Apelin-negative subgroup had significantly longer PFS period (49.8 months) compared with those of Apelin-negative (30.5 months). 


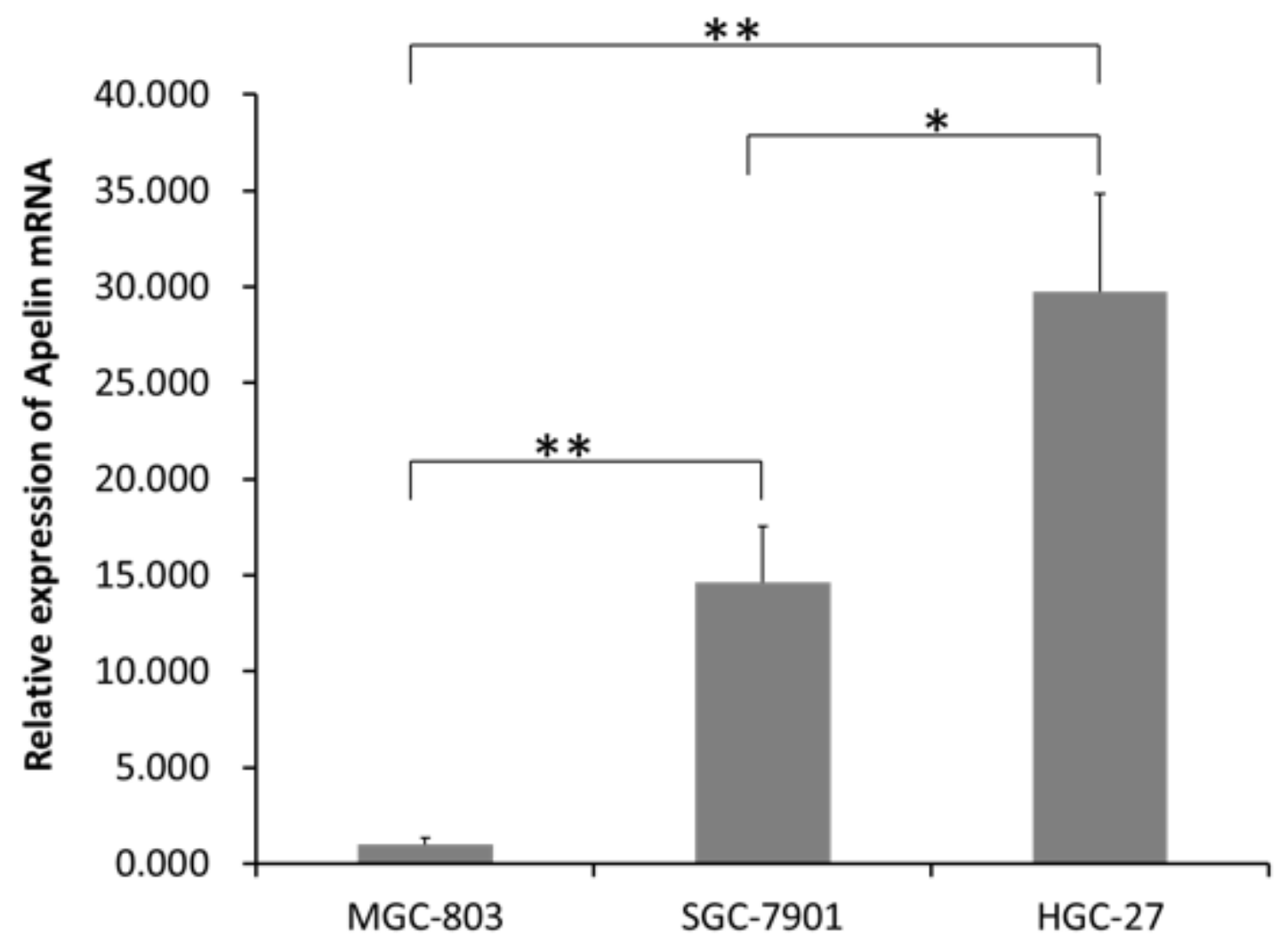

\section{Figure 6}

Expression of Apelin mRNA in different GC cell lines by RT-PCR. There was a statistical difference between two cell lines $₫ * P \llbracket 0.05 \rrbracket \star \star P \otimes 0.01 \rrbracket$
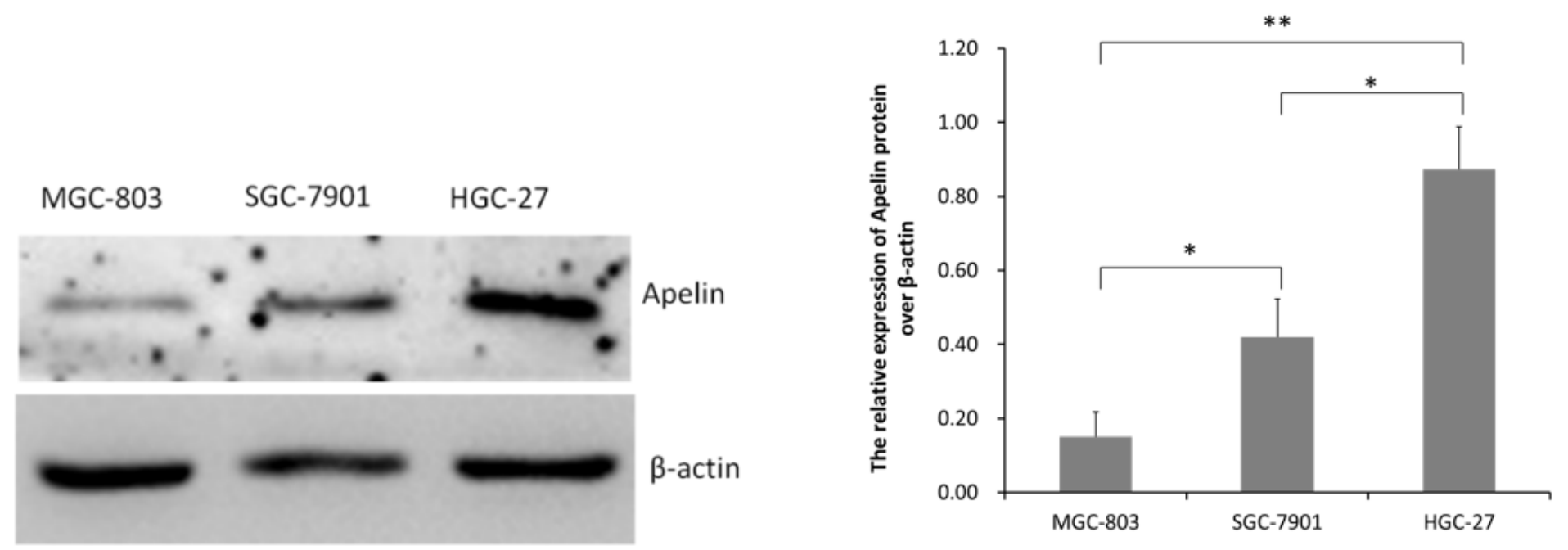

Figure 7

Expression of Apelin protein in different GC cell lines by Western blot analysis. There was a statistical difference between two cell lines $₫ * P \llbracket 0.05 \rrbracket * * P \llbracket 0.01 \rrbracket$ 


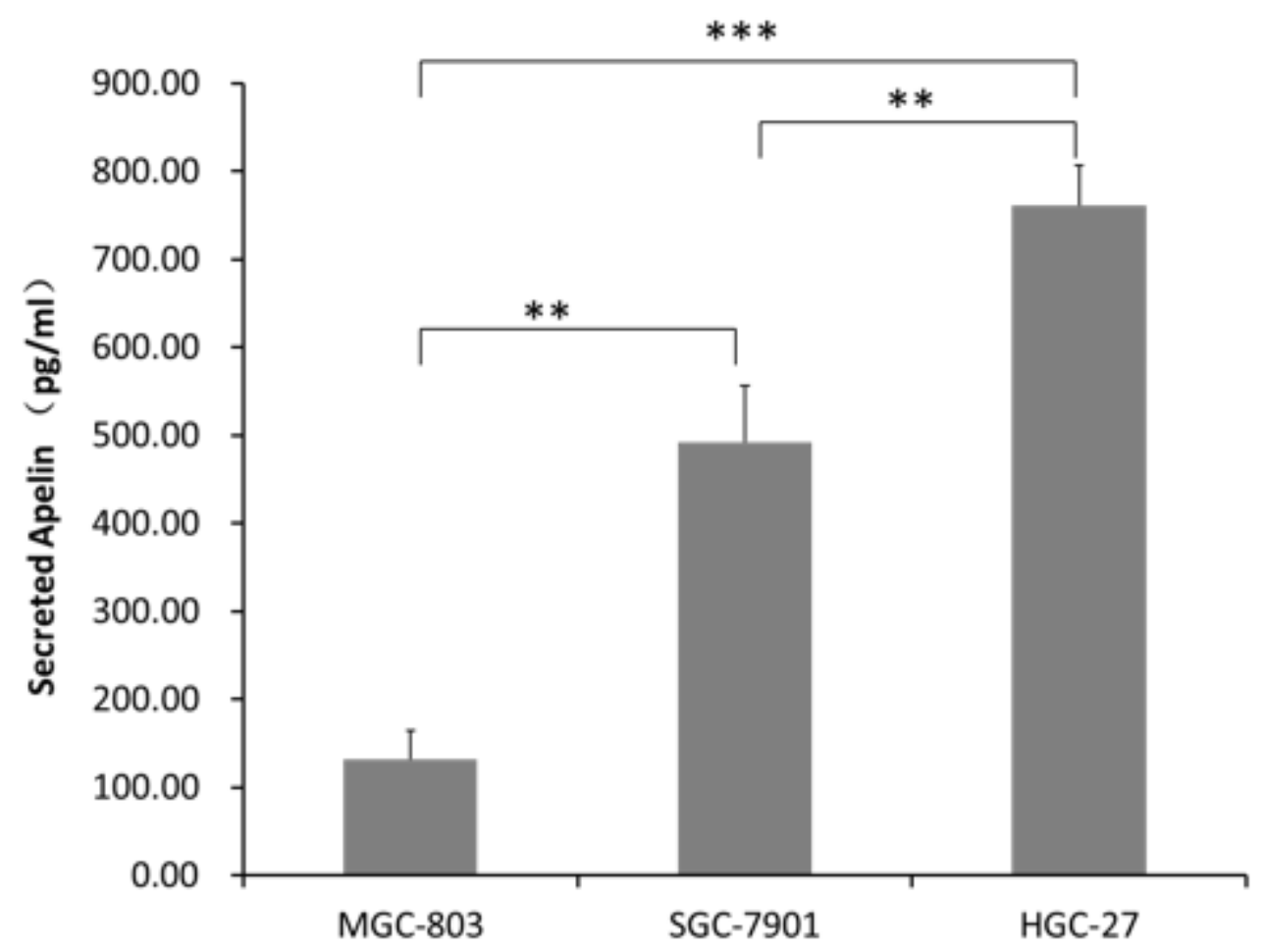

Figure 8

Levels of secreted Apelin protein in different GC cell lines verified by ELISA. There was a statistical difference between two cell lines $\rrbracket^{\star \star} P \llbracket 0.01 \rrbracket^{\star \star *} P \llbracket 0.001 \rrbracket$ 


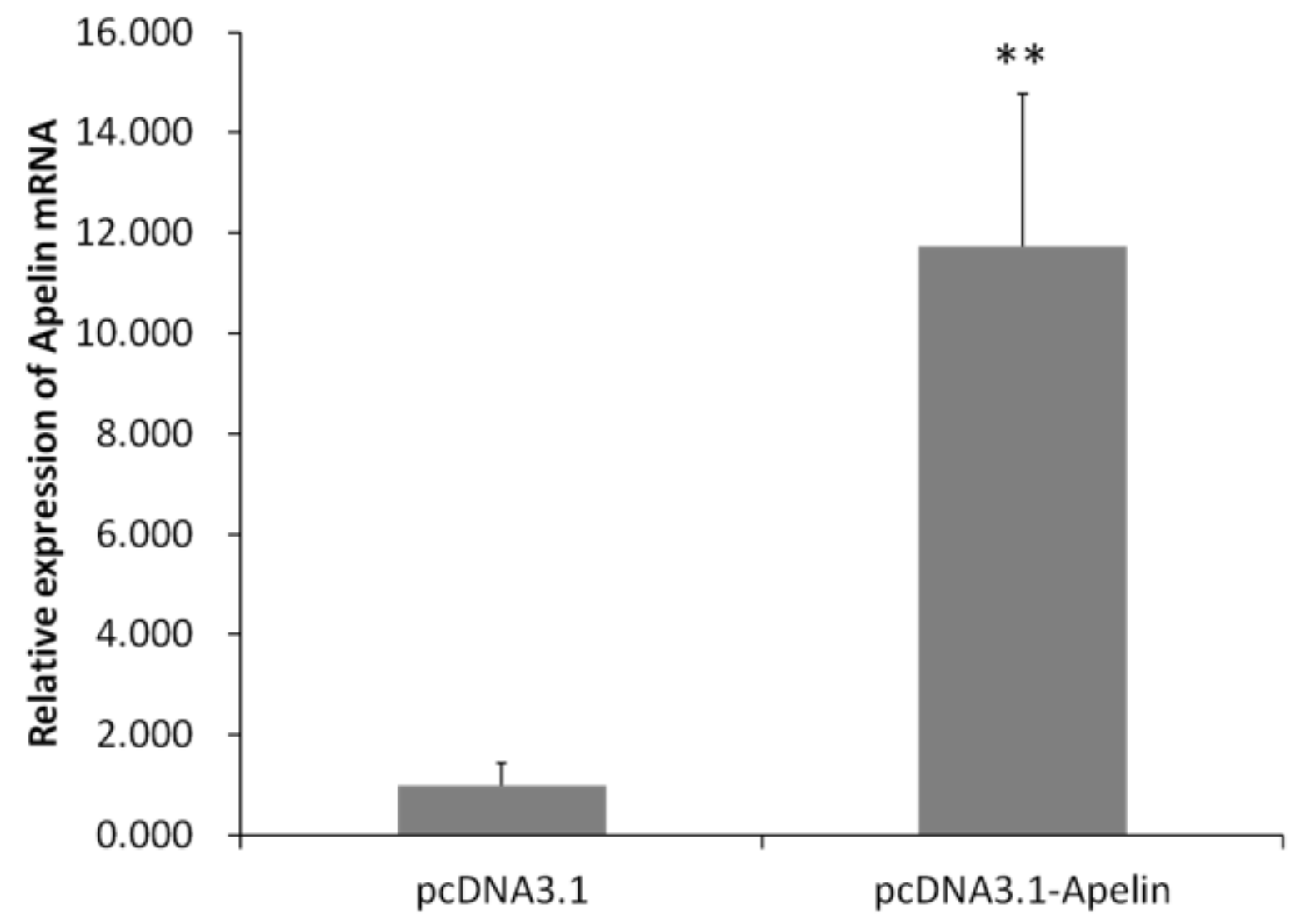

Figure 9

RT-PCR analysis of the relative expression of Apelin mRNA before and after transfection. When MGC-803 cells were transfected with pcDNA3.1-Apelin, the relative expression of Apelin was significantly elevated. (** $\mathrm{P} \otimes 0.01 \rrbracket$

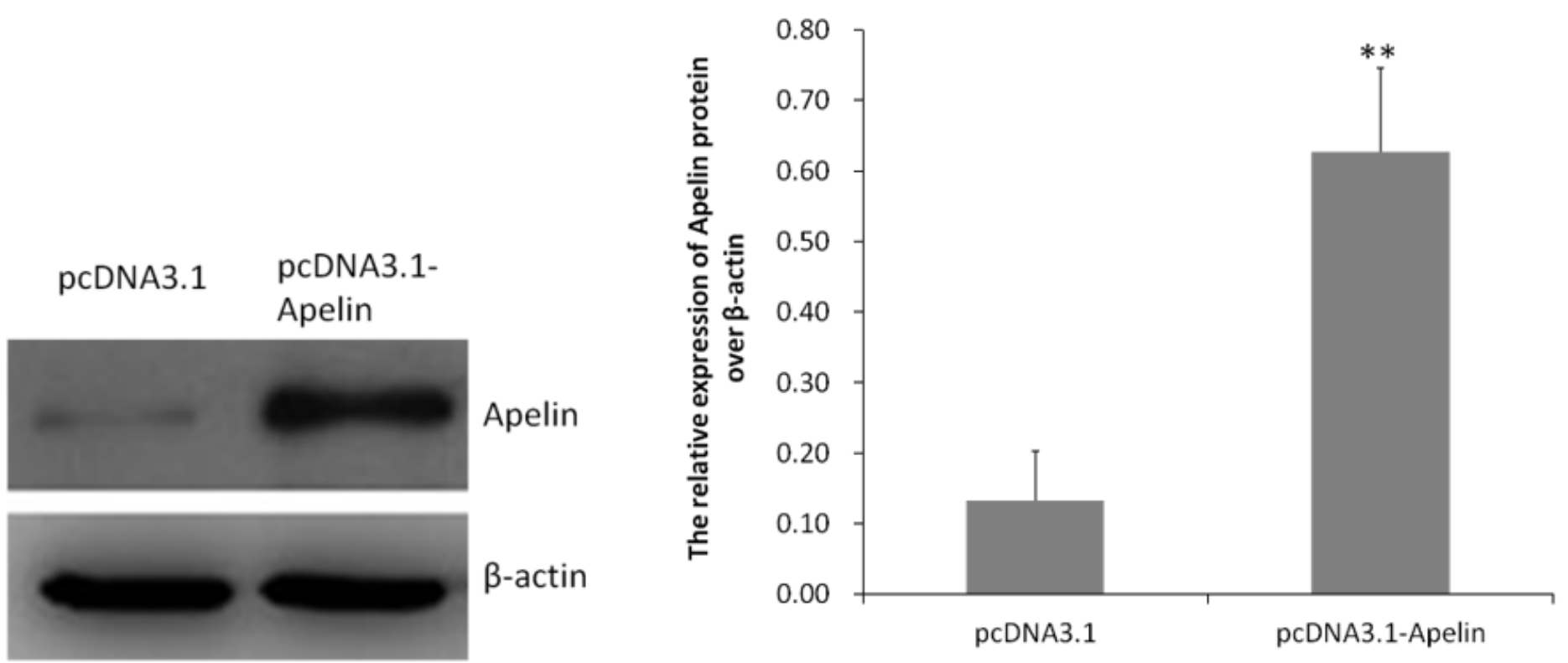


Figure 10

Western blot analysis for the expression of Apelin before and after transfection. When MGC-803 cells were transfected with pcDNA3.1-Apelin, the relative expression of Apelin protein in MGC-803 cells was significantly elevated. (**P囚0.01】

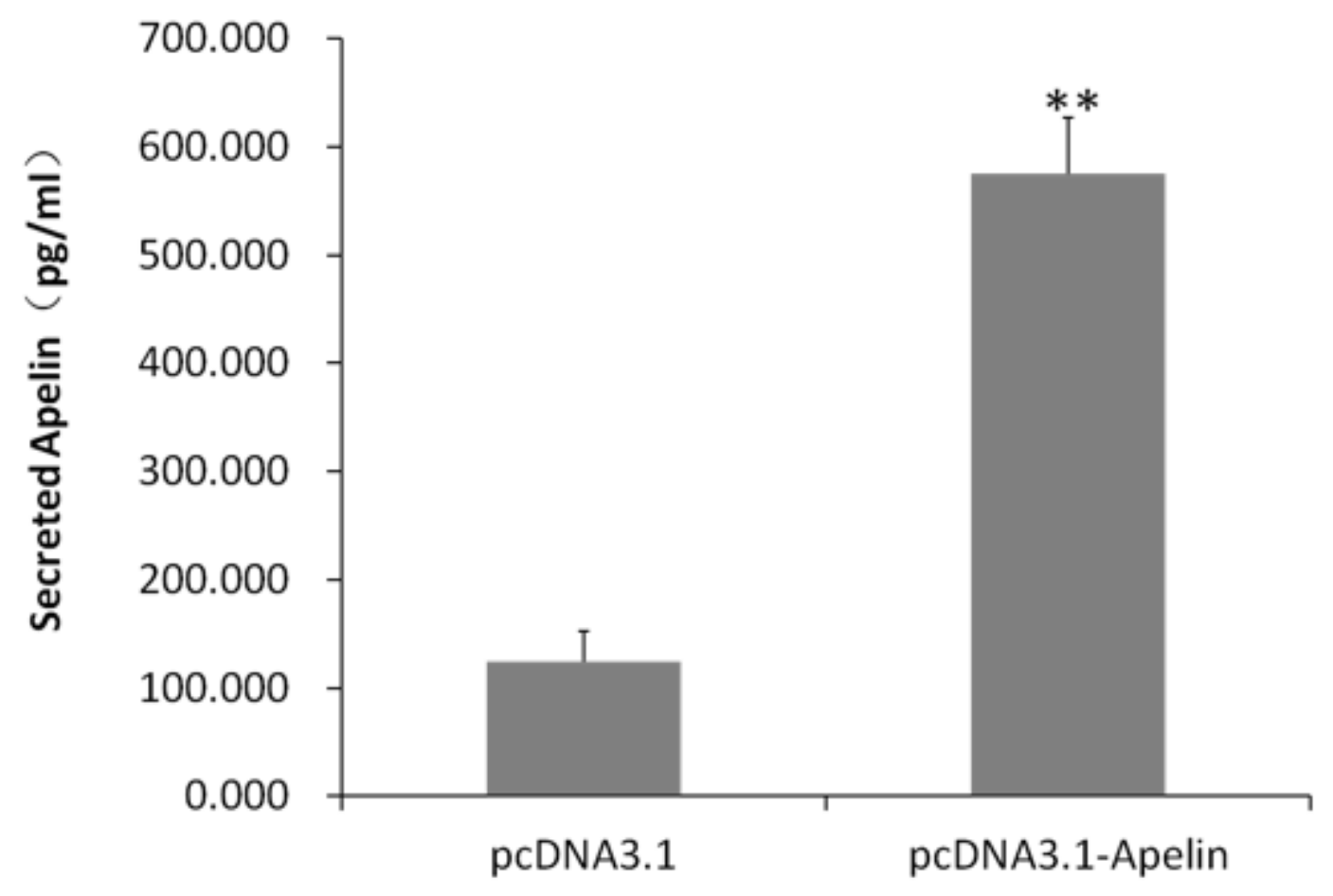

\section{Figure 11}

ELISA analysis of the expression of secreted Apelin protein before and after transfection. When MGC-803 cells were transfected with pcDNA3.1-Apelin, the relative expression of secreted Apelin in MGC-803 cells was significantly elevated $\mathbb{*}{ }^{*} \mathrm{P} \otimes 0.01 \rrbracket$ 


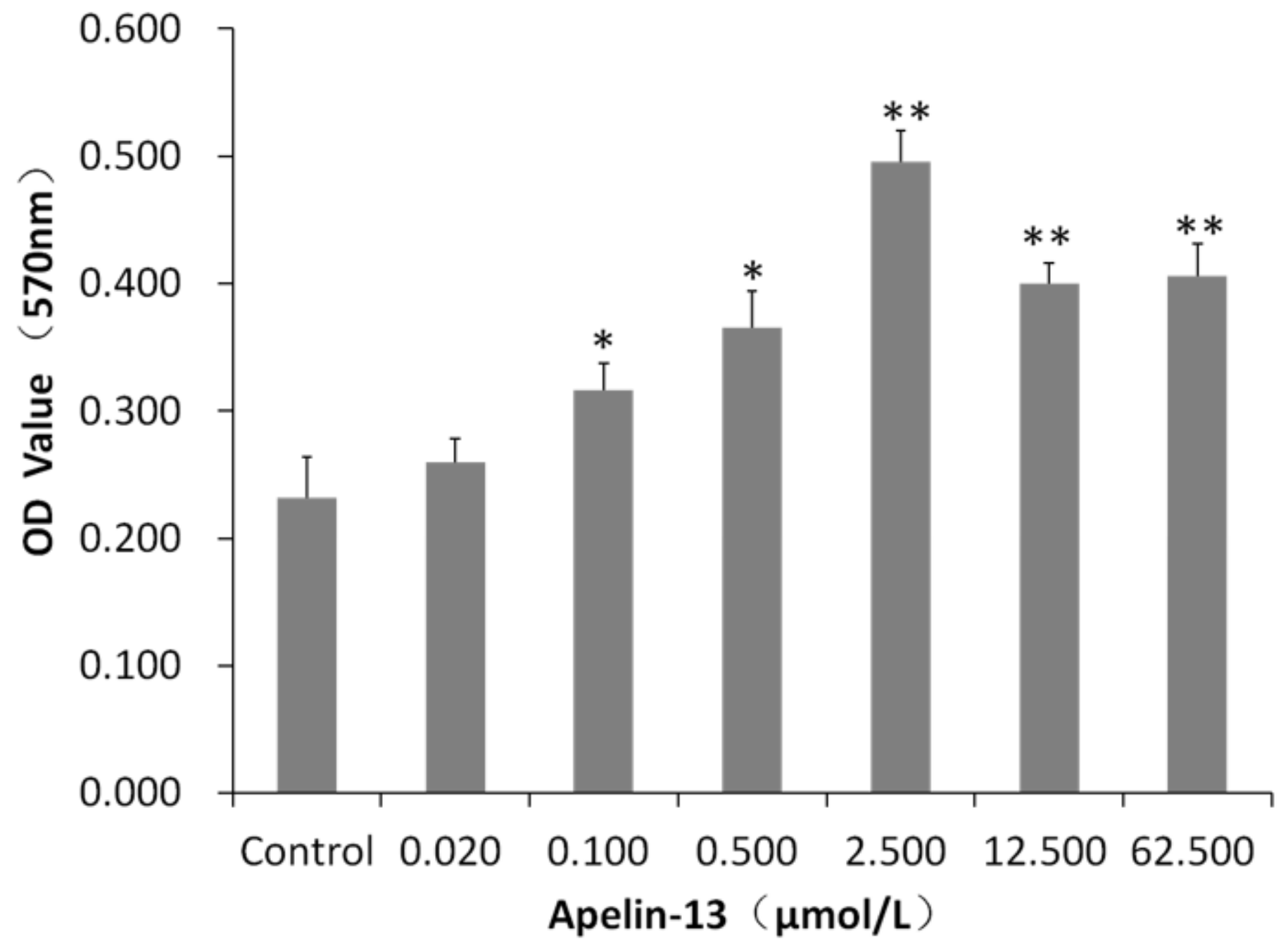

Figure 12

The proliferation of MGC-803 cells by MTT assay. Induced by different concentrations of Apelin-13 after 24 hours ( ${ }^{\star}$ Compared with the control group $\mathrm{P} \otimes 0.05,{ }^{*}$ Compared with the control group $\mathrm{P} \otimes 0.01$ ) 


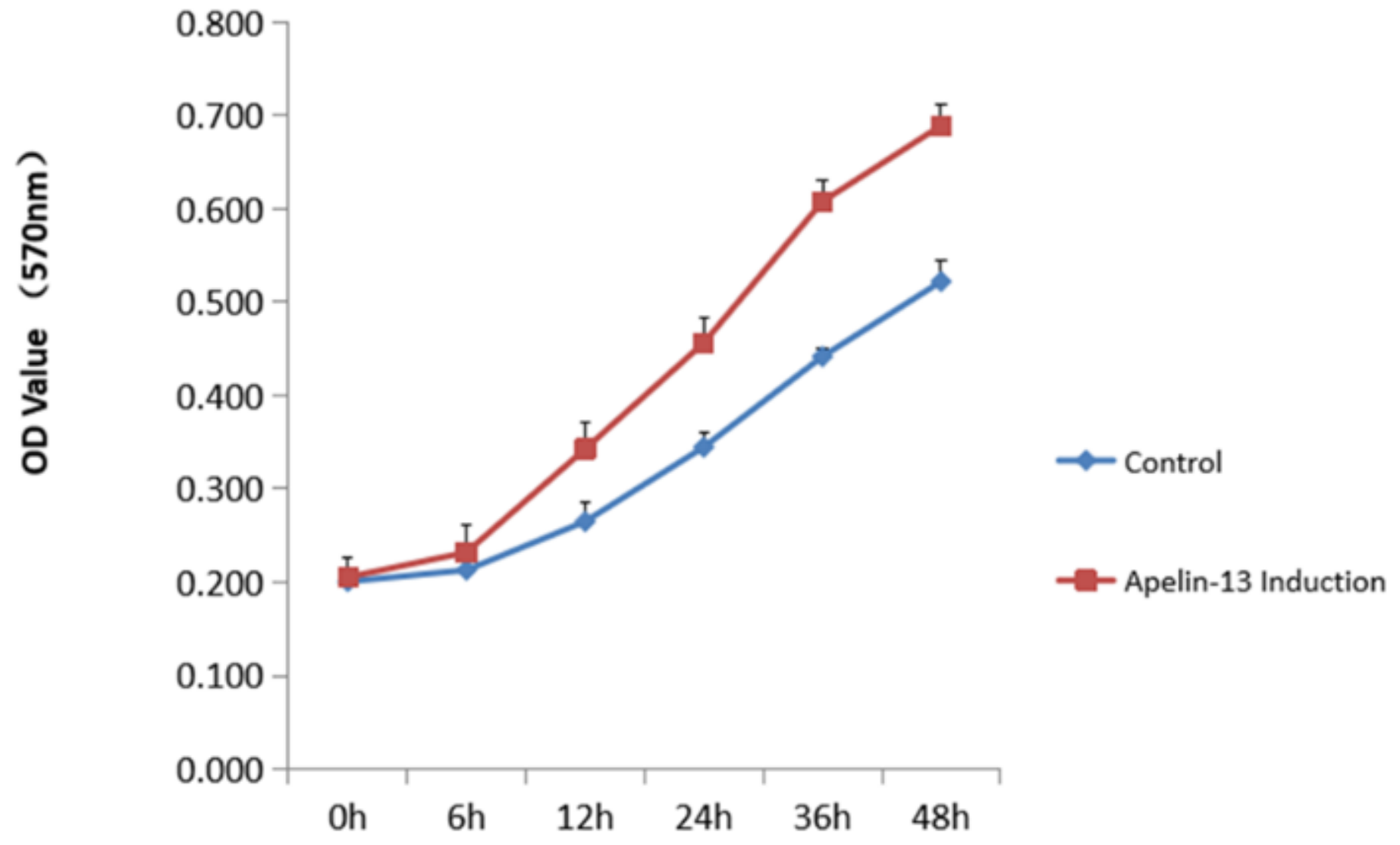

Figure 13

The proliferation of MGC-803 cells at different time points. The MGC-803 cells were induced by Apelin$13\left(2.5 \mu \mathrm{mol} / \mathrm{L}\right.$ ) by MTT assay. ( ${ }^{*}$ Compared with the control group P $₫ 0.05,{ }^{*}$ Compared with the control group $\mathrm{P} \otimes 0.01)$. 


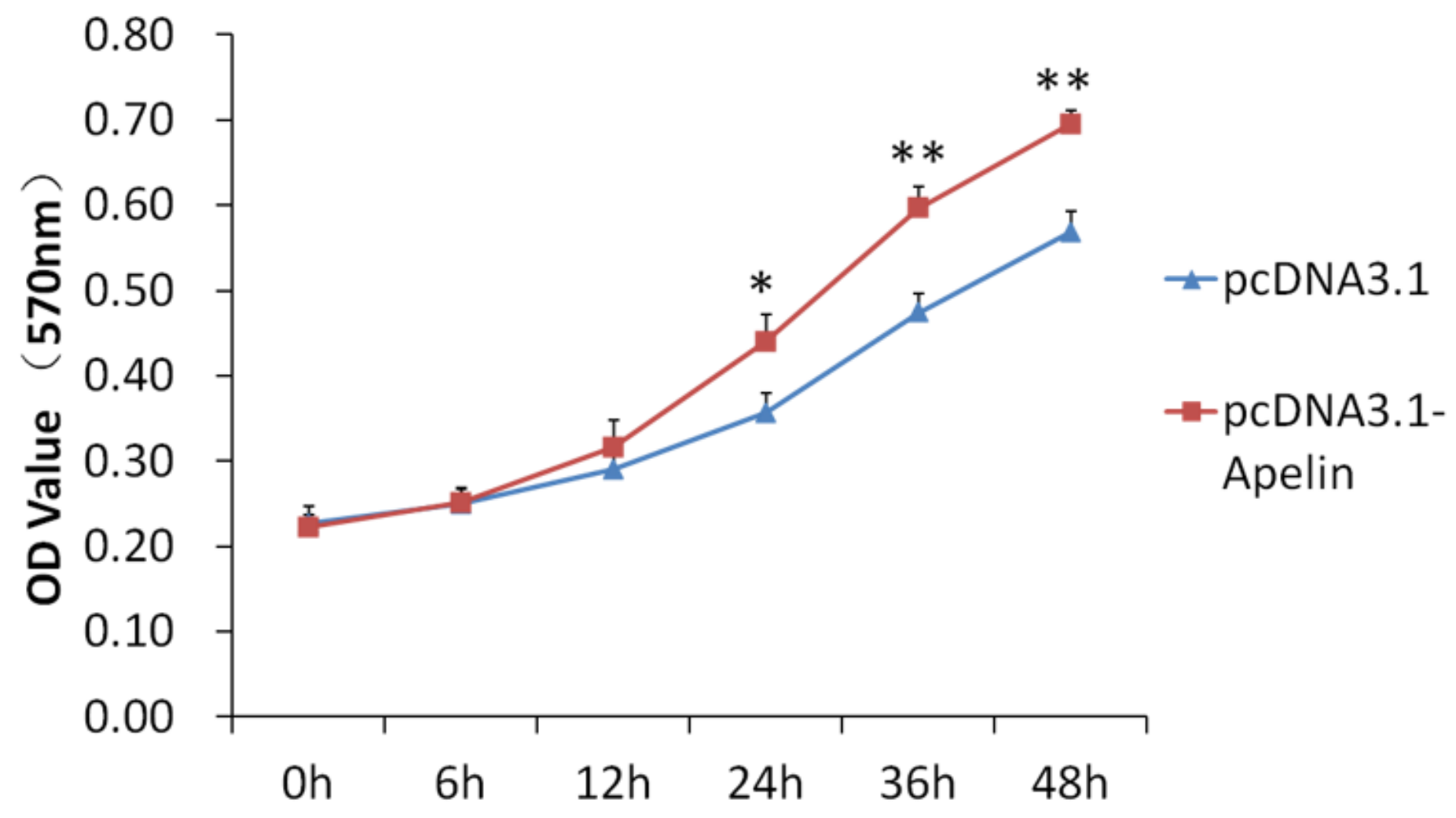

Figure 14

The proliferation after transfection by MTT assay. The proliferation of MGC-803 cells was measured transfected with pcDNA3.1-Apelin or pcDNA3.1 at different time point. ( ${ }^{*}$ Compared with the control group $\mathrm{P} \otimes 0.05,{ }^{*}$ Compared with the control group $\left.\mathrm{P} \otimes 0.01\right)$. 

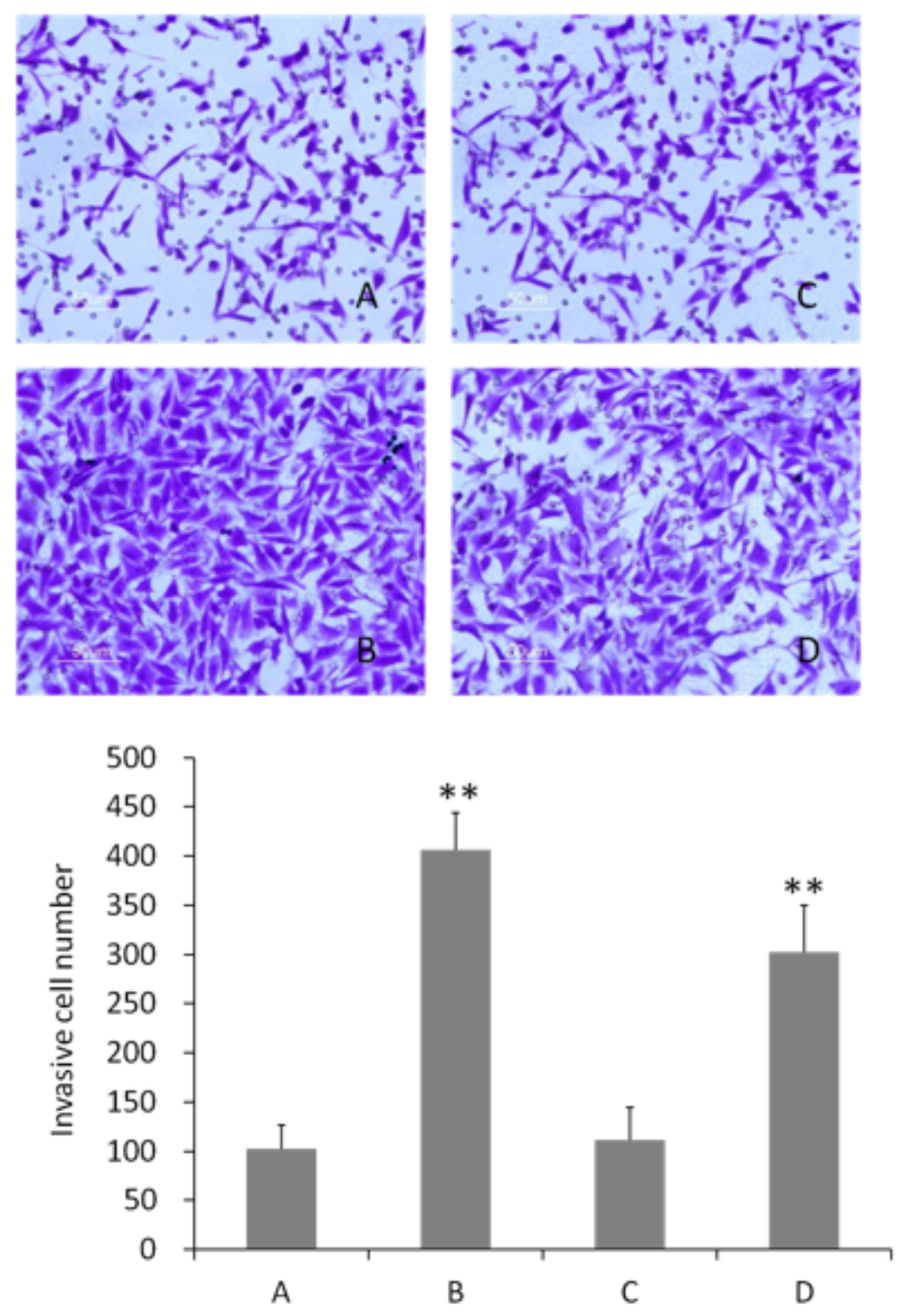

Figure 15

Effect of Apelin-13 induction and overexpression of Apelin on migration and invasion ability. Aimed at MGC-803 cells by Transwell assay. A囚Untreated group; B:Apelin-13 induction group; C:pcDNA3.1 transfected cells; D『pcDNA3.1-Apelin transfected cells. ( $* \star$ Compared with the control group Pख0.01). 


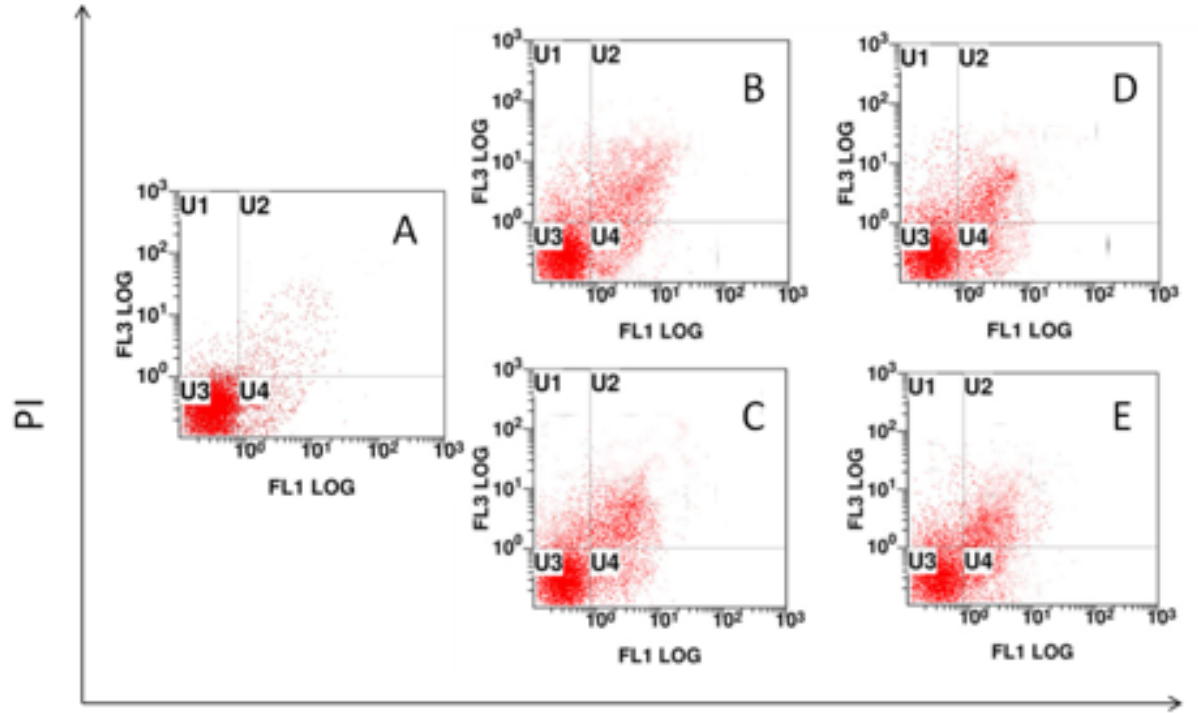

Annexin V-FITC

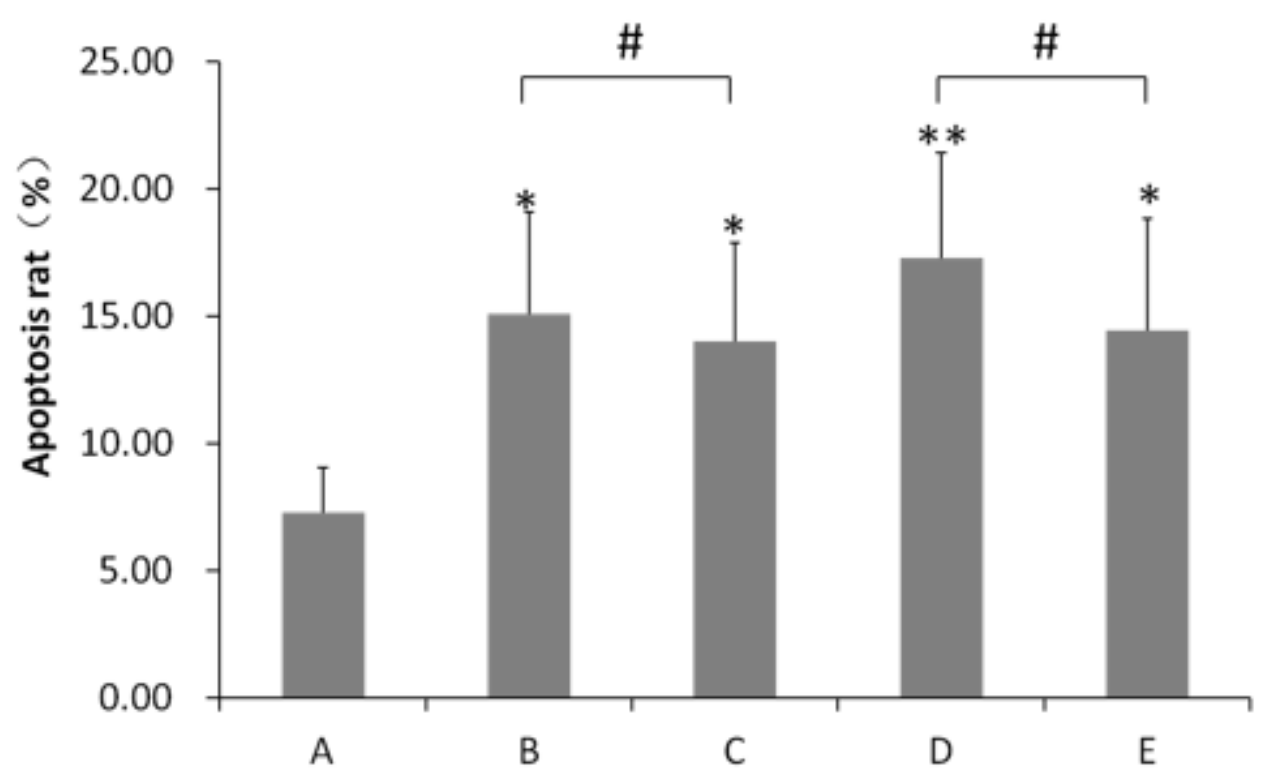

\section{Figure 16}

Effect of Apelin-13 induction and overexpression on apoptosis rate of MGC-803 cells by transwell assay. $A \bigotimes$ Untreated group; $B \bowtie S A H A$ induction group; $C \bowtie S A H A+A p e l i n-13$ induction group; $D \otimes S A H A$ induction +pcDNA3.1 transfection group; EखSAHA induction+ pcDNA3.1-Apelin transfection group. * Compared with

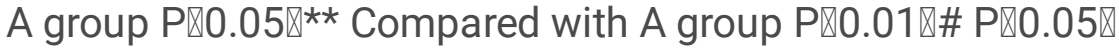




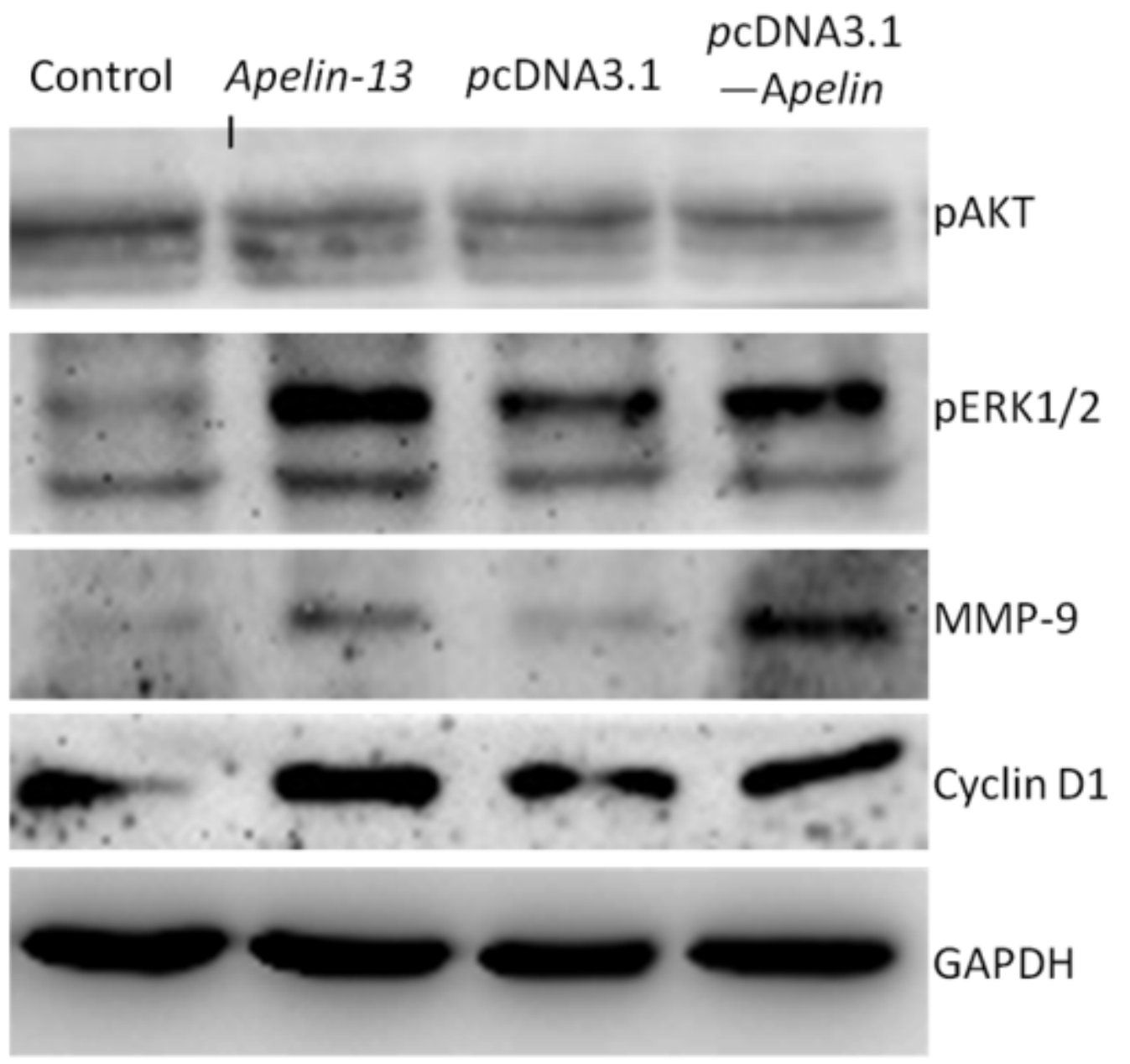

Figure 17

Western blot analysis of MGC-803 cells in different models. Including untreated cells, apeln-13 inducing cells (incubated with a concentration of $2.5 \mu \mathrm{mol} / \mathrm{L}$ for 24 hours), mock-vector transfected cells (24 hours after transfection with pcDNA3.1 vector) and pcDNA3.1-Apelin transfected cells (24 hours after transfection with pcDNA3.1-Apelin vector) 


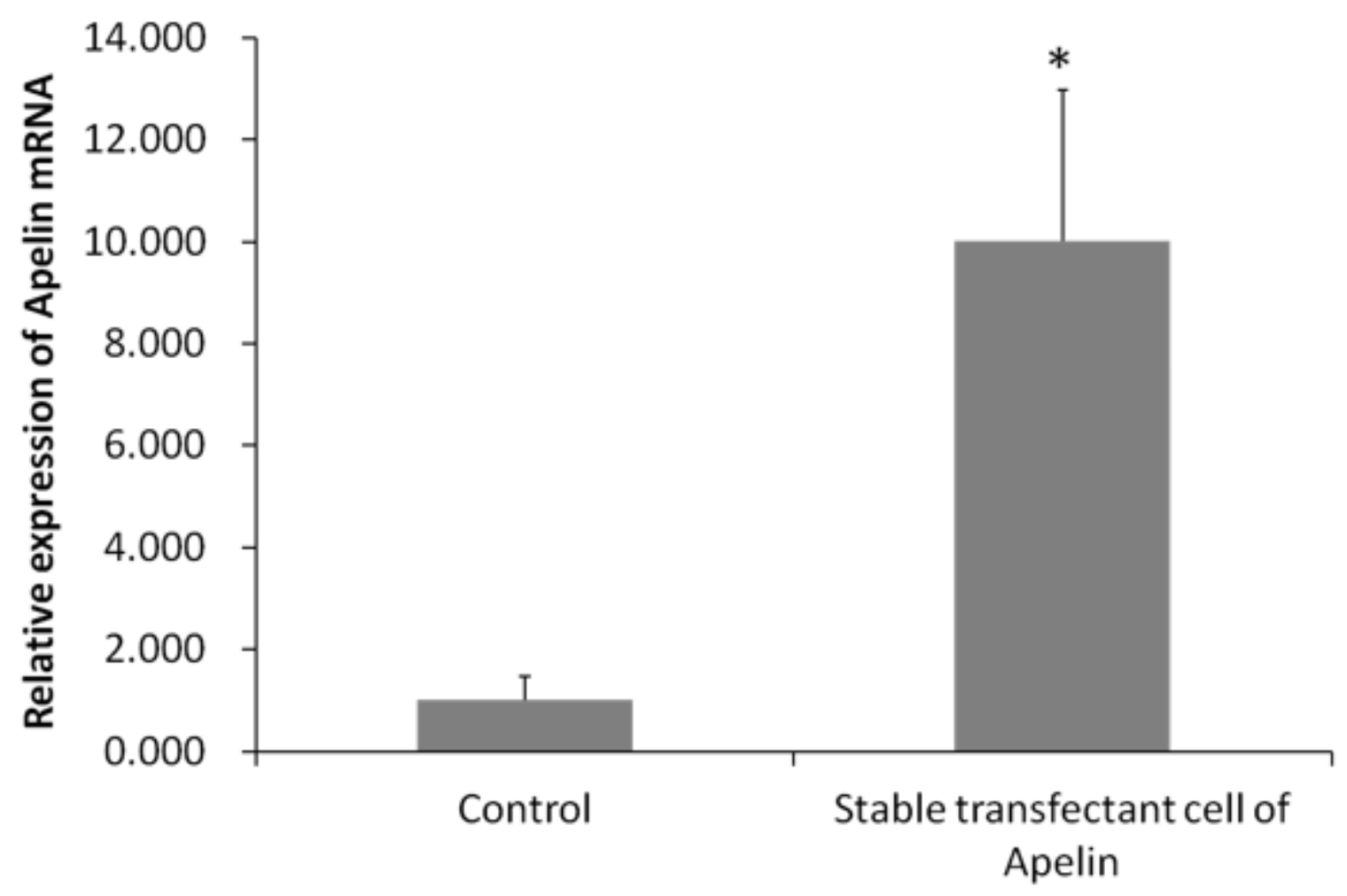

Figure 18

The relative expression levels of Apelin mRNA in vivo by RT-PCR analysis. There was a significant difference between stable transfected MGC-803 cells of over-expressed Apelin group and control $₫ * \mathrm{P} \rrbracket$ 0.05 \
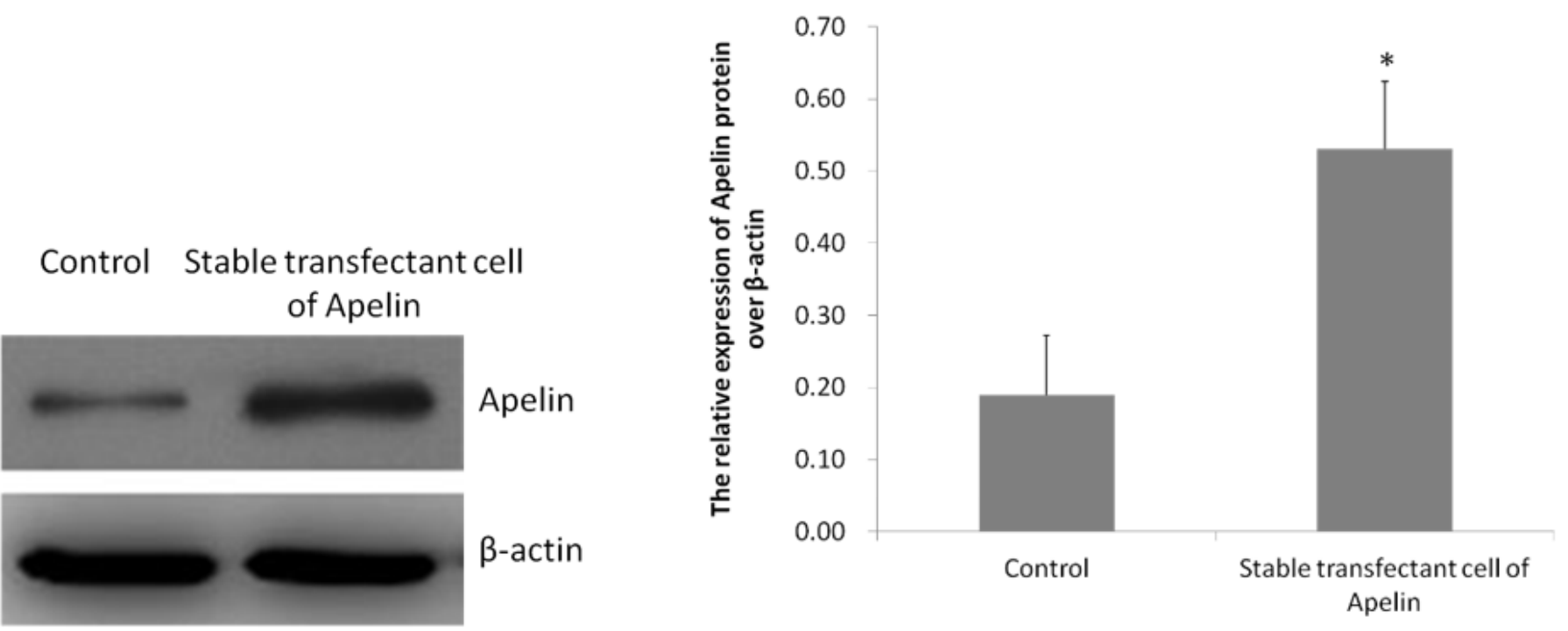

Figure 19 
The relative expression levels of Apelin-encoding protein by Western blot analysis in vivo. There was a significant difference between stable transfected MGC-803 cells of over-expressed Apelin group and control $₫ * P \otimes 0.05 \rrbracket$

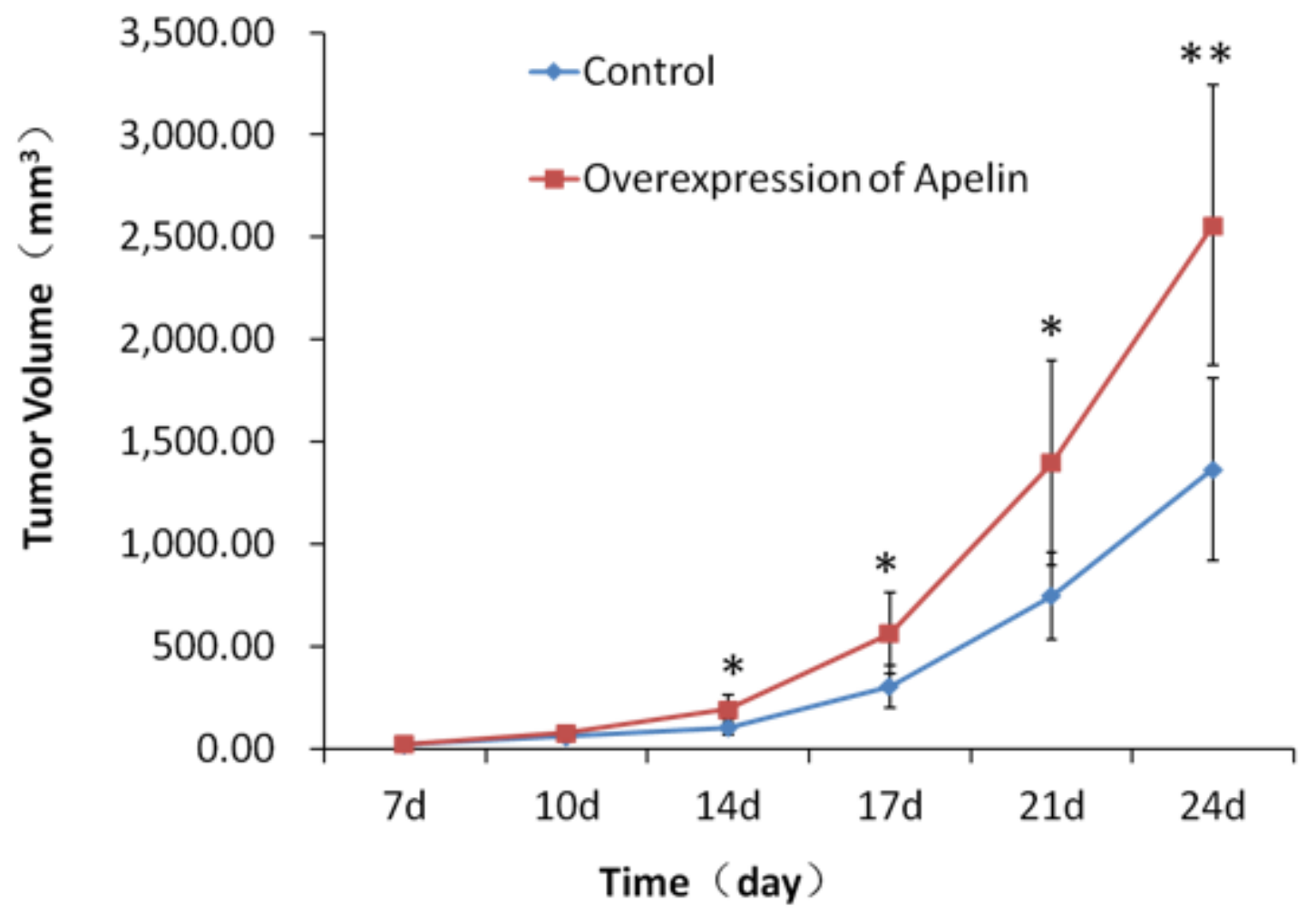

Figure 20

The tumor growth curves within 24 days in vivo. The subcutaneous over-expressed Apelin and control were separately injected into the nude mice. ( ${ }^{\star} \mathrm{Q} \otimes 0.05 \rrbracket \star * ~ P \llbracket 0.01 \rrbracket$
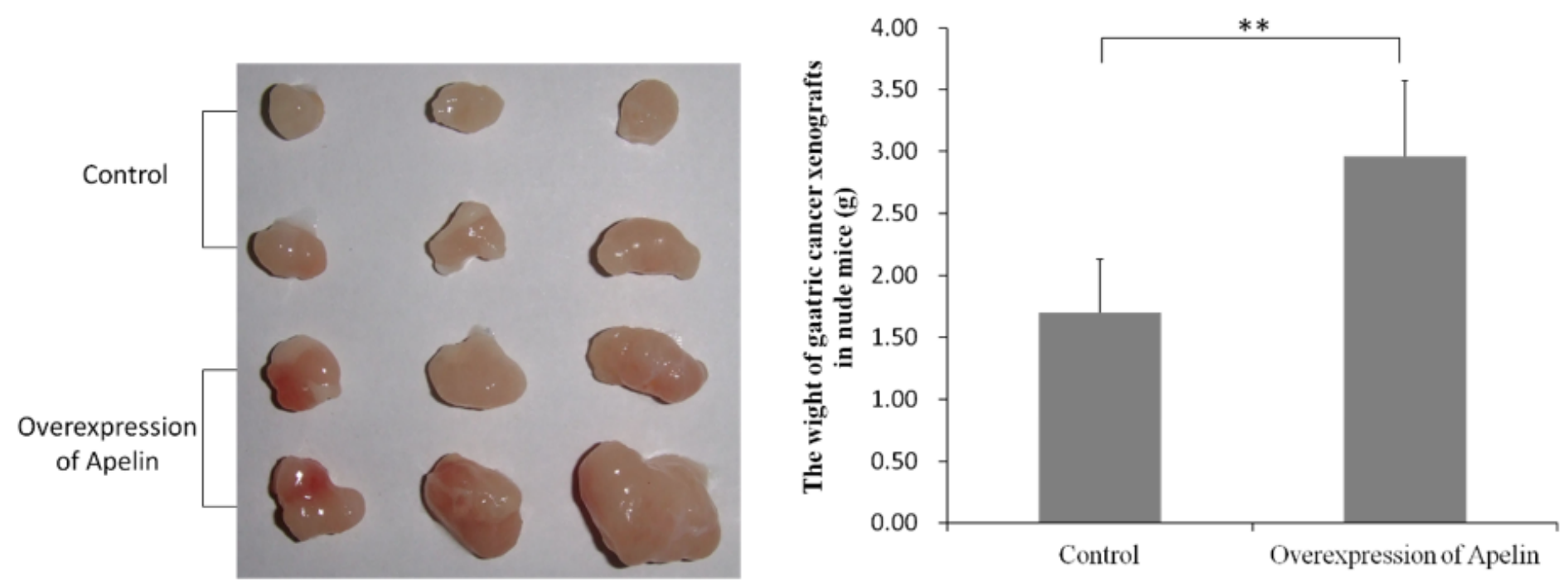

Figure 21 
The gastric cancer xenografts in nude mice. (A) The xenografts removed from the mice. (B) Mean tumor weight of over-expressed Apelin and control tumors
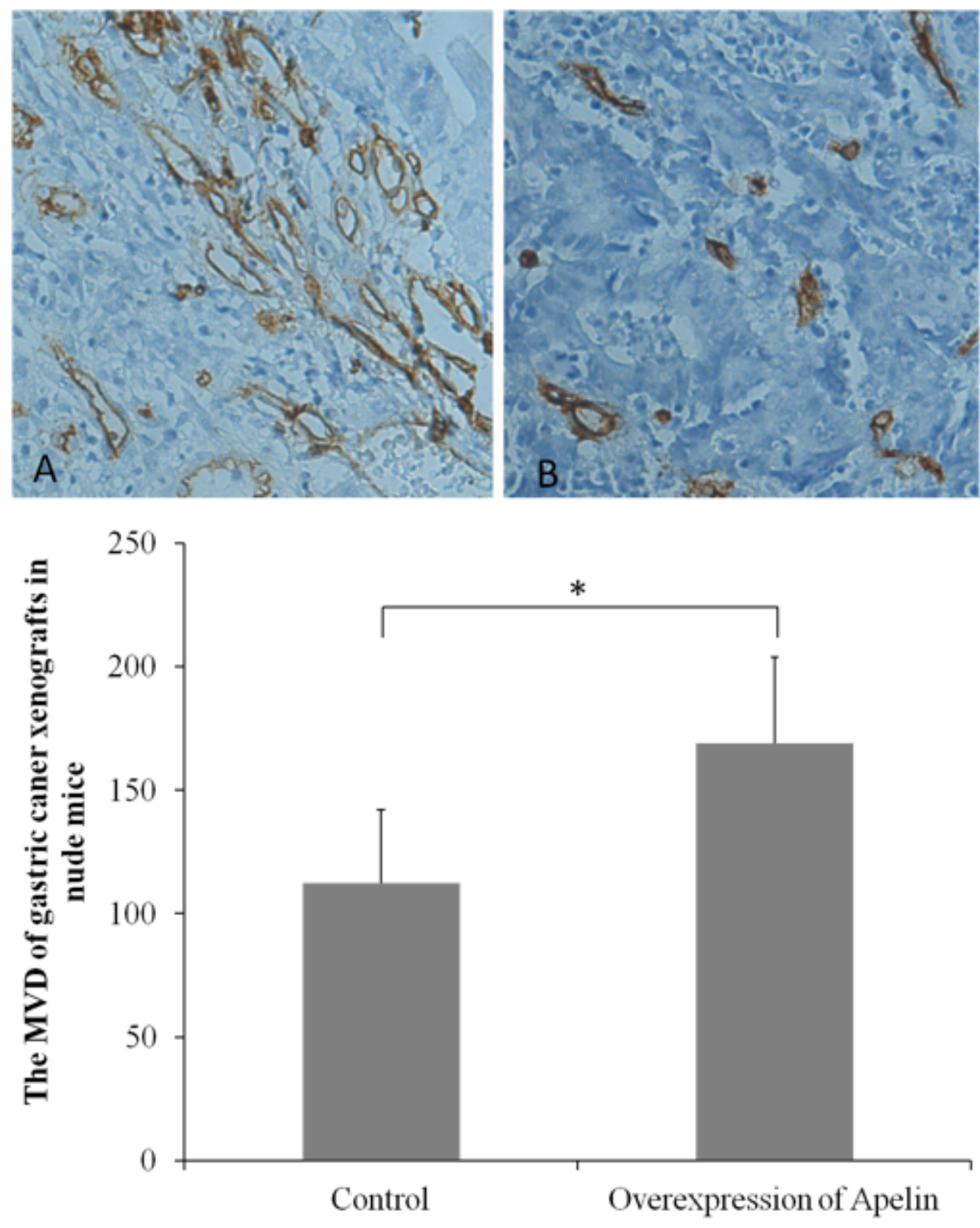

Figure 22

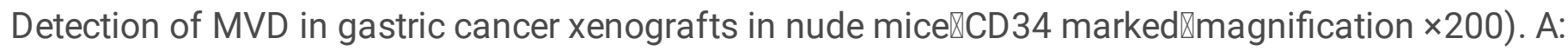
Xenografts tumors with over-expressed Apelin; B: Xenografts tumor with control (*P区0.05). 